Check for updates

Cite this: RSC Adv., 2017, 7, 25710

Received 7th February 2017

Accepted 30th April 2017

DOI: 10.1039/c7ra01550j

rsc.li/rsc-advances

\title{
Synthesis, biological evaluation and molecular docking of spirofurochromanone derivatives as anti-inflammatory and antioxidant agents $\dagger$
}

\author{
D. Ashok, (D)*a E. V. L. Madhuri, ${ }^{a}$ M. Sarasija, ${ }^{\text {b }}$ S. Sree Kanth, ${ }^{c}$ M. Vijjulatha, ${ }^{c}$ \\ Malini D. Alaparthi ${ }^{d}$ and S. R. Sagurthi*d
}

\begin{abstract}
A series of $2^{\prime}$-substituted-3' - methylspiro[cyclohexane-1,7'-furo[3,2-g]chroman]-5'(7'H)-one, 5a-i and 7au have been synthesized using an eco-friendly approach to attain good yields in a shorter reaction time. The structures of novel compounds were characterized by IR, ${ }^{1} \mathrm{H} N \mathrm{NMR},{ }^{13} \mathrm{C}$ NMR and mass spectrometry analysis. All the synthesized compounds were evaluated for their biological activity. Compounds $5 a, 5 b$, $5 c, 5 d, 5 e, 7 g, 7 h, 7 j, 7 l, 7 n$ and $7 q$ were found to have better anti-inflammatory activity in the albumin denaturation technique. All compounds exhibited good antioxidant activity by DPPH radical scavenging assay and most compounds showed activity in a hydrogen peroxide assay. Molecular docking scores as well biological assays results suggested that compound $7 \mathrm{~h}$ has better anti-inflammatory activity among the synthesized compounds.
\end{abstract}

\section{Introduction}

Reactions occurring in several types of tissue injuries, infections, immunologic stimulation as a defense against foreign or altered endogenous substances is termed as inflammation. The release of chemical mediators from injured tissue and migrating cells triggers inflammation. NSAIDs (Non-Steroidal Anti-Inflammatory Drugs) will be generally prescribed to overcome such physiological disturbances. The activity of NSAIDs in inflammatory diseases does not seem to be only due to the inhibition of the production of endogenous prostaglandins, but also by preventing the denaturation of proteins (which act as antigens and auto immune disease). ${ }^{1}$ Grant et al. ${ }^{2}$ stated that non-steroidal anti-inflammatory molecules will stabilize bovine serum albumin (BSA) when exposed to a few degree rises in temperature. Selecting therapeutically interesting molecules without the use of animals or living organisms used to be a challenge to the scientific community, which was well addressed by Williams et $a .^{3}$ by developing a technique of stabilizing thermal immunogenic bovine serum albumin by

${ }^{a}$ Green and Medicinal Chemistry Lab, Department of Chemistry, Osmania University, Hyderabad, Telangana, India-500007. E-mail: ashokdou@gmail.com

${ }^{b}$ Department of Chemistry, Satavahana University, Karimnagar, Telangana, India505001

${ }^{c}$ Molecular Modeling and Medicinal Chemistry Group, Department of Chemistry, University College of Science, Osmania University, Hyderabad, Telangana, India500007

${ }^{d}$ Department of Genetics, Drug Design \& Molecular Medicine Lab, Osmania University, Hyderabad, Telangana, India-500007. E-mail: drsomeswar@osmania.ac.in

$\dagger$ Electronic supplementary information (ESI) available. See DOI: $10.1039 / \mathrm{c} 7 \mathrm{ra01550j}$ natural products. It is also revealed that a range of extracts and compounds with various biological properties can convey the stability to the protein. ${ }^{4}$ Thus, rather than just detecting nonsteroidal anti-inflammatory agents, the bovine serum albumin denaturation assay could have a wider application.

Biaryl units as molecular components has attracted enormous interest and their syntheses have been widely carried out and have yielded innumerable compounds with diverse biological activities such as: anti-inflammatory, antimicrobial, antifungal, antiproliferative, antidiabetic, immunosuppressant, analgesic, antioxidant. ${ }^{5}$ The Suzuki cross-coupling reaction, which represents an attractive and alternative methods that use organometallic species for the construction of unsymmetrical biaryl compounds, involves air and moisture stable organoboranes that possess relatively low toxicity and also has broad functional group tolerance. Catalysts used in the Suzuki reaction have been traditionally based on homogeneous palladium phosphine complexes. ${ }^{5}$ The study for improving the reactivity of Suzuki reactions, water or aqueous-organic mixtures has received attention due to the ability of the base to dissolve in water for activating arylboronic acids. ${ }^{6}$

Benzofurans are interesting oxygen containing heterocycles which are ubiquitous in nature and show a wide range of biological activities, ${ }^{7}$ as analgesics, ${ }^{8}$ antidepressants, ${ }^{9}$ antitumor agent. ${ }^{10}$ Similarly chromanone derivatives, in particular 2-spirochroman-4(1H)-ones are embodied in many bio-active molecules (Fig. 1) and possess various biological activities which include antiarrhythmic, ${ }^{11}$ anti-HIV ${ }^{12}$ antidiabetic, ACC inhibitor, ${ }^{13}$ vanilloid receptor antagonist, growth hormone secretagogues, ${ }^{14}$ histamine receptor antagonist, antiviral ${ }^{15}$ and antiinflammatory. ${ }^{16}$ Spirochromanone ring system represents an 
<smiles>O=C1CC2(CCN(Cc3ccccc3)CC2)Oc2ccccc21</smiles><smiles></smiles><smiles>COc1c2ccoc2cc2oc(C)cc(=O)c12</smiles>

\section{1 '-Benzylspiro[chroman-2,4'-piperidin]-4-one}

Nokhel

\section{Visnagin}

Fig. 1 Bioactive molecules.

important class of naturally occurring substances characterized by highly pronounced biological properties.

The combination of two or more pharmacophores or chemical entities either linked with one another or fused together to create a new molecule is referred to as molecular hybridization, ${ }^{17}$ which aims to combat drug resistance and enrich existing arsenals of anti-infective agents. ${ }^{18}$ The selection of the pharmacophores is based upon their known bioprofiles, with the hope that the resulting hybrid molecules may exhibit synergistic or additive pharmacological activities. ${ }^{19}$
Potential availability of benzofuran and spirochromanone made us to synthesize some new spirofurochromanone-biaryl derivatives using Suzuki coupling by the combination of two green chemistry principles, namely microwave assisted synthesis and aqueous phase reactions. Hybrid compounds containing benzofuran and spirochromanone moieties, called spirofurochromanone, due to combined effect may exhibit better biological profile. Enabling technologies for organic syntheses such as microwave, aqueous phase reactions or green solvents have changed organic chemistry in terms of efficiency,

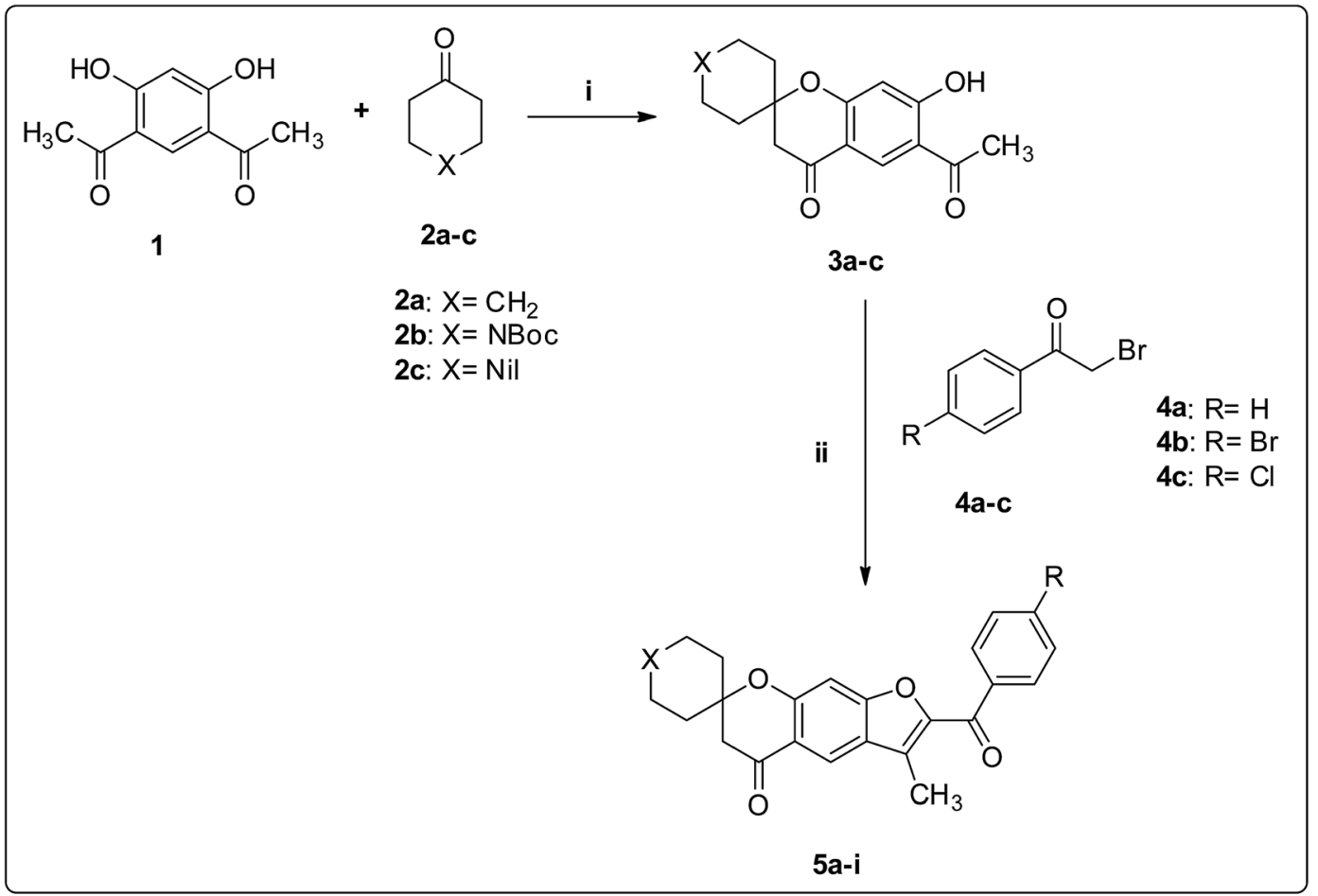
5a: $\mathrm{X}=\mathrm{CH}_{2}, \mathrm{R}=\mathrm{H}$
5b: $X=$ NBoc, $\mathrm{R}=\mathrm{H}$
5c: $X=$ Nil, $R=H$
5d: $\mathrm{X}=\mathrm{CH}_{2}, \mathrm{R}=\mathrm{Br}$
5e: $X=$ NBoc, $R=B r$
5f: $X=$ Nil, $R=B r$
5g: $\mathrm{X}=\mathrm{CH}_{2}, \mathrm{R}=\mathrm{Cl}$
5h: $\mathrm{X}=\mathrm{NBoc}, \mathrm{R}=\mathrm{Cl}$
5i: $\mathrm{X}=$ Nil, $\mathrm{R}=\mathrm{Cl}$

Scheme 1 Synthesis of compounds $5 \mathrm{a}-\mathrm{i}$. Reagents and conditions: (i) toluene, pyrrolidine, reflux, $3 \mathrm{~h}$. (ii) (method a) $\mathrm{K}_{2} \mathrm{CO}_{3}$, acetone, $\Delta$ (method b) $\mathrm{K}_{2} \mathrm{CO}_{3}, \mathrm{MWI}$. 
work-up and speed. Microwave assisted organic synthesis leads to rate enhancement with excellent reproducibility, improved yields and less side reactions compared to conventional heating. ${ }^{20}$

In continuation to our efforts ${ }^{21-23}$ to synthesize new biaryl heterocyclic derivatives using eco-friendly approach, we have synthesized spirofurochromanone derivatives $\mathbf{5 a - i}$ and $7 \mathbf{a}-\mathbf{u}$ from compounds 3a-c using microwave irradiation and conventional heating. All the compounds were well characterised by spectral data. Synthesized spirofurochromanone were screened for in vitro scavenging activity utilizing

Table 1 Comparison of yields of compounds $5 a-i$ at different synthetic conditions

\begin{tabular}{|c|c|c|c|c|c|c|c|}
\hline \multirow[b]{2}{*}{ Entry } & \multirow[b]{2}{*}{$X$} & \multirow[b]{2}{*}{$\mathrm{R}$} & \multirow[b]{2}{*}{$\mathrm{Mp},{ }^{\circ} \mathrm{C}$} & \multicolumn{2}{|c|}{$\begin{array}{l}\text { Conventional } \\
\text { heating }\end{array}$} & \multicolumn{2}{|c|}{$\begin{array}{l}\text { Microwave } \\
\text { irradiation }\end{array}$} \\
\hline & & & & $\begin{array}{l}\text { Time, } \\
\mathrm{h}\end{array}$ & $\begin{array}{l}\text { Yield }^{a}, \\
\%\end{array}$ & $\begin{array}{l}\text { Time, } \\
\text { min }\end{array}$ & $\begin{array}{l}\text { Yield }^{a}, \\
\%\end{array}$ \\
\hline $5 a$ & $\mathrm{CH}_{2}$ & $\mathrm{H}$ & $128-130$ & 3 & 57 & 5 & 82 \\
\hline $5 b$ & NBoc & $\mathrm{H}$ & $220-222$ & 4 & 57 & 8 & 84 \\
\hline $5 c$ & Nil & $\mathrm{H}$ & $78-70$ & 3 & 35 & 5 & 71 \\
\hline $5 d$ & $\mathrm{CH}_{2}$ & $\mathrm{Br}$ & $148-150$ & 3 & 58 & 5 & 83 \\
\hline $5 e$ & NBoc & $\mathrm{Br}$ & $224-226$ & 4 & 70 & 8 & 80 \\
\hline $5 f$ & Nil & $\mathrm{Br}$ & $130-132$ & 3 & 50 & 5 & 77 \\
\hline $5 g$ & $\mathrm{CH}_{2}$ & $\mathrm{Cl}$ & $126-128$ & 3 & 70 & 5 & 79 \\
\hline $5 h$ & NBoc & $\mathrm{Cl}$ & $218-220$ & 4 & 72 & 8 & 77 \\
\hline $5 i$ & Nil & $\mathrm{Cl}$ & $125-127$ & 3 & 55 & 5 & 80 \\
\hline
\end{tabular}

hydrogen peroxide and DPPH assay. These tested compounds shown high scavenging activity when compared with standard ascorbic acid.

\section{Results and discussions}

\subsection{Chemistry}

The desired spirofurochromanone scaffolds were synthesized in three steps as outlined (Scheme 1). Selective synthesis of monospiro chromanone derivatives $3 \mathbf{a}-\mathbf{c}$ were achieved from diacetyl resorcinol 1 with cyclic alkanones 2a-c involving Kabbe condensation with pyrrolidine as base and toluene as solvent. ${ }^{24}$ Further reaction of $\mathbf{3 a} \mathbf{a}-\mathbf{c}$ with $4^{\prime}$-substituted phenacyl bromide 4a-c in presence of potassium carbonate as base resulted in spirofurochromanone 5a-i with good yields in conventional heating and microwave irradiation methods as shown in Table 1 . Finally the target compounds $7 \mathbf{a}-\mathbf{u}$ were synthesized by reaction of compound $\mathbf{5 d - f}$ with arylboronic acids $\mathbf{6 a}-\mathbf{g}$ in conventional heating and microwave irradiation methods (Scheme 2).

In our initial attempts in conventional method for the synthesis of compound $7 \mathbf{a}$ from $\mathbf{5 d}$, based on the previous experience of Suzuki coupling reactions in our research group, ${ }^{25}$ we started with $10 \mathrm{~mol} \% \mathrm{Pd}\left(\mathrm{PPh}_{3}\right)_{4}$ as catalyst, $\mathrm{Na}_{2} \mathrm{CO}_{3}$ as a base and 1 equiv. of phenylboronic acid $6 \mathbf{a}$ as a model reaction at $80^{\circ} \mathrm{C}$ for $10 \mathrm{~h}$ under $\mathrm{N}_{2}$ atmosphere in DMF, ethanol as well as in dioxane separately, which resulted in very poor yields. Among them ethanol was found to be a better solvent with relatively better yield. Literature reports shows that addition of water as co-solvent to the polar aprotic solvents greatly improves the rate of reaction. ${ }^{26}$

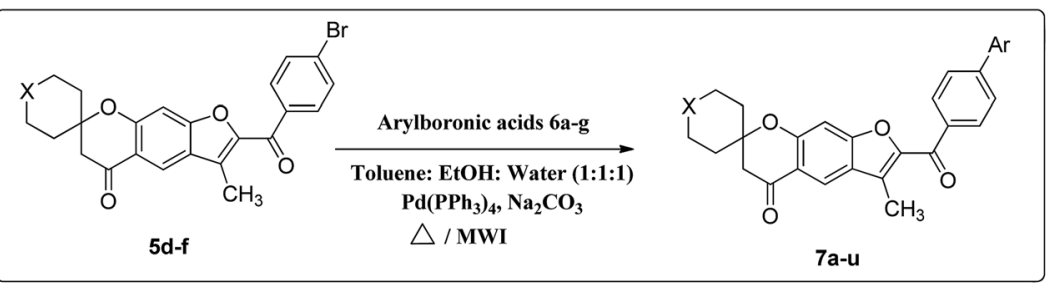

7a: $\mathrm{X}=\mathrm{CH}_{2}, \mathrm{Ar}=\mathrm{Ph}$

7b: $\mathrm{X}=\mathrm{CH}_{2}, \mathrm{Ar}=4-\mathrm{CHO}-\mathrm{C}_{6} \mathrm{H}_{4}$

7c: $\mathrm{X}=\mathrm{CH}_{2}, \mathrm{Ar}=4-\mathrm{Cl}-\mathrm{C}_{6} \mathrm{H}_{4}$

7d: $\mathrm{X}=\mathrm{CH}_{2}, \mathrm{Ar}=4-\mathrm{CH}_{3}-\mathrm{C}_{6} \mathrm{H}_{4}$

7e: $\mathrm{X}=\mathrm{CH}_{2}, \mathrm{Ar}=1$-Naphthyl

7f: $\mathrm{X}=\mathrm{CH}_{2}, \mathrm{Ar}=3,5-\operatorname{diCl}-\mathrm{C}_{6} \mathrm{H}_{3}$

7g: $\mathrm{X}=\mathrm{CH}_{2}, \mathrm{Ar}=4-\mathrm{F}-\mathrm{C}_{6} \mathrm{H}_{4}$

7h: $\mathrm{X}=\mathrm{NBoc}, \mathrm{Ar}=\mathrm{Ph}$

7i: $\mathrm{X}=\mathrm{NBoc}, \mathrm{Ar}=4-\mathrm{CHO}-\mathrm{C}_{6} \mathrm{H}_{4}$

7j: $\mathrm{X}=\mathrm{NBoc}, \mathrm{Ar}=4-\mathrm{Cl}-\mathrm{C}_{6} \mathrm{H}_{4}$

7k: $\mathrm{X}=\mathrm{NBoc}, \mathrm{Ar}=4-\mathrm{CH}_{3}-\mathrm{C}_{6} \mathrm{H}_{4}$ 7l: $\mathrm{X}=$ NBoc, $\mathrm{Ar}=1-$ Naphthyl

7m:X= NBoc, $\mathrm{Ar}=3,5-\mathrm{diCl}-\mathrm{C}_{6} \mathrm{H}_{3}$

7n: $\mathrm{X}=\mathrm{NBoc}, \mathrm{Ar}=4-\mathrm{F}-\mathrm{C}_{6} \mathrm{H}_{4}$

7o: $\mathrm{X}=\mathrm{Nil}, \mathrm{Ar}=\mathrm{Ph}$

7p: $\mathrm{X}=\mathrm{Nil}, \mathrm{Ar}=4-\mathrm{CHO}-\mathrm{C}_{6} \mathrm{H}_{4}$

7q: $\mathrm{X}=\mathrm{Nil}, \mathrm{Ar}=4-\mathrm{Cl}-\mathrm{C}_{6} \mathrm{H}_{4}$

7r: $\mathrm{X}=\mathrm{Nil}, \mathrm{Ar}=4-\mathrm{CH}_{3}-\mathrm{C}_{6} \mathrm{H}_{4}$

7s: $\mathrm{X}=$ Nil, Ar = 1-Naphthyl

7t: $\mathrm{X}=\mathrm{Nil}, \mathrm{Ar}=3,5-\mathrm{diCl}-\mathrm{C}_{6} \mathrm{H}_{3}$

7u: $\mathrm{X}=\mathrm{Ni1}, \mathrm{Ar}=4-\mathrm{F}-\mathrm{C}_{6} \mathrm{H}_{4}$

Scheme 2 Synthesis of compounds $7 a-u$. 
Thus we decided to check with combination of solvents with water. Using 1:1 solvent water mixture, the reaction proceeded well furnishing improved yields in shorter time as shown in Table 2. The Suzuki coupled products were obtained in shorter time and high yield in $1: 1: 1$ solvent mixture of ethanol, toluene and water. Using the same solvents, reaction was carried out in a sealed tube by conventional heating and the yields are listed in Table 2. Encouraged by the results obtained, we subsequently attempted to carry out the reaction under mild conditions and reduced reaction time by the application of microwave irradiation.

Microwave irradiation at $180 \mathrm{~W}$, keeping similar conditions the reactions were completed within few minutes and increased yields of the product were obtained. Having established the optimal conditions for the reaction, compounds $5 \mathbf{d}, \mathbf{5 e}$ and $\mathbf{5 f}$ were subjected to react with different substituted arylboronic acids $\mathbf{6 a - g}$ to give $7 \mathbf{a}-\mathbf{u}$. The comparative studies based on the optimization of both methods are reflected in Table 3 . All the compounds synthesized were well characterized by spectral data.

\subsection{Biological activity}

All the newly synthesized compounds $\mathbf{5 a - i}$ and $7 \mathbf{a}-\mathbf{u}$ were screened for their anti-inflammatory and antioxidant activities. The in vitro anti-inflammatory and antioxidant activities of the synthesized $5 \mathbf{a}-\mathbf{i}$ and $7 \mathbf{a}-\mathbf{u}$ are tabulated (Tables 4 and 5).

2.2.1 Anti-inflammatory studies. The anti-inflammatory activity of the precursors $5 \mathbf{a}-\mathbf{i}$ and synthesized compounds $7 \mathbf{a}-\mathbf{u}$ were tested for their in vitro anti-inflammatory activity by using

Table 2 Screening of different solvents

\begin{tabular}{|c|c|c|c|c|c|c|c|}
\hline \multirow[b]{2}{*}{ Entry } & \multirow[b]{2}{*}{ Solvent } & \multicolumn{2}{|c|}{ Conventional heating } & \multicolumn{2}{|c|}{$\begin{array}{l}\text { Conventional heating in } \\
\text { sealed pressure tube }\end{array}$} & \multicolumn{2}{|c|}{ Microwave irradiation } \\
\hline & & Time, $\mathrm{h}$ & Yield $^{a}, \%$ & Time, $\mathrm{h}$ & Yield $^{a}, \%$ & Time, min & Yield $^{a}, \%$ \\
\hline $7 \mathbf{a}$ & DMF & 10 & 10 & 8 & 20 & 40 & 40 \\
\hline $7 \mathbf{a}$ & DMF/water $(1: 1)$ & 9 & 25 & 7 & 30 & 25 & 40 \\
\hline $7 \mathbf{a}$ & Dioxane & 10 & 17 & 8 & 26 & 40 & 37 \\
\hline $7 \mathbf{a}$ & EtOH/water $(1: 1)$ & 9 & 35 & 7 & 40 & 25 & 57 \\
\hline $7 \mathbf{a}$ & EtOH/toluene/water $(1: 1: 1)$ & 8 & 70 & 6 & 75 & 20 & 83 \\
\hline
\end{tabular}

Table 3 Reaction conditions for synthesis of products $7 a-u$

\begin{tabular}{|c|c|c|c|c|c|c|c|}
\hline \multirow[b]{2}{*}{ Entry } & \multirow[b]{2}{*}{$\mathrm{x}$} & \multirow[b]{2}{*}{$\mathrm{Ar}$} & \multirow[b]{2}{*}{$\mathrm{Mp},{ }^{\circ} \mathrm{C}$} & \multicolumn{2}{|c|}{$\begin{array}{l}\text { Sealed tube, conventional } \\
\text { heating }\end{array}$} & \multicolumn{2}{|c|}{ Microwave irradiation } \\
\hline & & & & Time, h & Yield $^{a}, \%$ & Time, min & Yield $^{a}, \%$ \\
\hline $7 \mathbf{a}$ & $\mathrm{CH}_{2}$ & $\mathrm{Ph}$ & $172-174$ & 6 & 75 & 20 & 83 \\
\hline $7 \mathbf{b}$ & $\mathrm{CH}_{2}$ & 4-CHO- $\mathrm{C}_{6} \mathrm{H}_{4}$ & $168-170$ & 6 & 74 & 22 & 82 \\
\hline $7 \mathrm{c}$ & $\mathrm{CH}_{2}$ & $4-\mathrm{Cl}-\mathrm{C}_{6} \mathrm{H}_{4}$ & $186-188$ & 6 & 74 & 20 & 84 \\
\hline $7 f$ & $\mathrm{CH}_{2}$ & $3,5-\mathrm{DiCl}-\mathrm{C}_{6} \mathrm{H}_{3}$ & $178-180$ & 6 & 74 & 20 & 85 \\
\hline $7 \mathrm{~g}$ & $\mathrm{CH}_{2}$ & $4-\mathrm{F}-\mathrm{C}_{6} \mathrm{H}_{4}$ & $170-172$ & 6 & 77 & 22 & 84 \\
\hline $7 \mathbf{h}$ & NBoc & $\mathrm{Ph}$ & $205-207$ & 7 & 76 & 23 & 82 \\
\hline $7 \mathbf{i}$ & NBoc & $4-\mathrm{CHO}-\mathrm{C}_{6} \mathrm{H}_{4}$ & $210-212$ & 7 & 71 & 25 & 80 \\
\hline $7 \mathbf{j}$ & NBoc & $4-\mathrm{Cl}-\mathrm{C}_{6} \mathrm{H}_{4}$ & $218-220$ & 7 & 74 & 23 & 83 \\
\hline $7 \mathbf{k}$ & NBoc & 4-Me- $\mathrm{C}_{6} \mathrm{H}_{4}$ & $224-227$ & 7 & 77 & 23 & 85 \\
\hline $7 \mathbf{p}$ & Nil & 4-CHO- $\mathrm{C}_{6} \mathrm{H}_{4}$ & $182-184$ & 6 & 76 & 21 & 88 \\
\hline $7 q$ & Nil & $4-\mathrm{Cl}-\mathrm{C}_{6} \mathrm{H}_{4}$ & $138-140$ & 6 & 75 & 20 & 83 \\
\hline $7 \mathbf{r}$ & Nil & $4-\mathrm{Me}-\mathrm{C}_{6} \mathrm{H}_{4}$ & $126-128$ & 6 & 74 & 20 & 85 \\
\hline $7 s$ & Nil & 1-Naphthyl & $170-172$ & 6 & 75 & 20 & 84 \\
\hline $7 t$ & Nil & $3,5-\mathrm{DiCl}-\mathrm{C}_{6} \mathrm{H}_{3}$ & $187-188$ & 6 & 76 & 20 & 88 \\
\hline $7 \mathbf{u}$ & Nil & $4-\mathrm{F}-\mathrm{C}_{6} \mathrm{H}_{4}$ & $138-140$ & 6 & 73 & 20 & 85 \\
\hline
\end{tabular}

${ }^{a}$ Isolated yield. 
Table 4 Anti-inflammatory activity of compounds $5 a-i$ and $7 a-u$

\begin{tabular}{lcll}
\hline & $\begin{array}{l}\text { Anti-inflammatory } \\
\text { activity }^{a} \text { IC }_{50} \\
\left(\mu \mathrm{ML}^{-1}\right)\end{array}$ & Compound & $\begin{array}{l}\text { Anti-inflammatory } \\
\text { activity }^{a} \text { IC }_{50} \\
\left(\mu \mathrm{M} \mathrm{mL}^{-1}\right)\end{array}$ \\
\hline $\mathbf{5 a}$ & $\mathbf{1 1 0 . 5 8} \pm \mathbf{0 . 7 8}$ & $\mathbf{7 g}$ & $\mathbf{9 7 . 3 9} \pm \mathbf{0 . 7 6}$ \\
$\mathbf{5 b}$ & $\mathbf{7 7 . 9 4} \pm \mathbf{1 . 0 0}$ & $\mathbf{7 h}$ & $\mathbf{7 7 . 1 1} \pm \mathbf{0 . 6 6}$ \\
$\mathbf{5 c}$ & $132.0 \pm 1.02$ & $\mathbf{7 i}$ & $142.31 \pm 0.64$ \\
$\mathbf{5 d}$ & $\mathbf{1 0 5 . 6 1} \pm \mathbf{0 . 5 9}$ & $\mathbf{7 j}$ & $\mathbf{1 0 8 . 9 7} \pm \mathbf{0 . 8 5}$ \\
$\mathbf{5 e}$ & $\mathbf{9 8 . 4 6} \pm \mathbf{0 . 9 0}$ & $\mathbf{7 k}$ & $\mathbf{1 2 0 . 4 8} \pm 0.88$ \\
$\mathbf{5 f}$ & $159.17 \pm 1.00$ & $\mathbf{7 l}$ & $\mathbf{1 0 8 . 4 9} \pm \mathbf{0 . 7 4}$ \\
$\mathbf{5 g}$ & $127.55 \pm 0.86$ & $\mathbf{7 m}$ & $\mathbf{1 5 2 . 7 7} \pm 0.89$ \\
$\mathbf{5 h}$ & $140.48 \pm 1.29$ & $\mathbf{7 n}$ & $\mathbf{1 1 6 . 1 0} \pm \mathbf{1 . 1 0}$ \\
$\mathbf{5 i}$ & $152.81 \pm 0.92$ & $\mathbf{7 0}$ & $130.92 \pm 0.94$ \\
$\mathbf{7 a}$ & $154.07 \pm 0.71$ & $\mathbf{7 p}$ & $137.42 \pm 0.76$ \\
$\mathbf{7 b}$ & $118.3 \pm 0.95$ & $\mathbf{7 e}$ & $\mathbf{1 0 2 . 8 2} \pm \mathbf{0 . 7 0}$ \\
$\mathbf{7 c}$ & $164.09 \pm 1.15$ & $\mathbf{7 r}$ & $\mathbf{1 7 2 . 0 4} \pm 0.93$ \\
$\mathbf{7 d}$ & $140.85 \pm 1.02$ & $\mathbf{7 s}$ & $168.42 \pm 0.74$ \\
$\mathbf{7 e}$ & $170.41 \pm 0.74$ & $\mathbf{7 t}$ & $\mathbf{1 4 5 . 3 3} \pm 0.91$ \\
$\mathbf{7 f}$ & $128.99 \pm 0.87$ & $\mathbf{7 u}$ & $127.59 \pm 0.75$ \\
Aspirin & $116.48 \pm 0.98$ & & \\
${ }^{a}$ Values & & &
\end{tabular}

Table 5 Antioxidant DPPH activity of compounds $5 a-i$ and $7 a-u$

\begin{tabular}{|c|c|c|c|}
\hline Compound & $\begin{array}{l}\mathrm{DPPH}^{a} \mathrm{IC}_{50} \\
\left(\mu \mathrm{g} \mathrm{mL} \mathrm{L}^{-1}\right)\end{array}$ & Compound & $\begin{array}{l}\mathrm{DPPH}^{a} \mathrm{IC}_{50} \\
\left(\mu \mathrm{g} \mathrm{mL} \mathrm{m}^{-1}\right)\end{array}$ \\
\hline $5 \mathbf{a}$ & $8.16 \pm 1.41$ & $7 \mathrm{~g}$ & $3.93 \pm 1.06$ \\
\hline $5 \mathbf{b}$ & $6.84 \pm 1.51$ & $7 \mathrm{~h}$ & $63.92 \pm 1.02$ \\
\hline $5 c$ & $8.81 \pm 1.24$ & $7 \mathbf{i}$ & $56.17 \pm 1.17$ \\
\hline $5 d$ & $2.64 \pm 1.14$ & $7 \mathbf{j}$ & $10.16 \pm 1.25$ \\
\hline $5 e$ & $10.16 \pm 1.39$ & $7 \mathbf{k}$ & $6.84 \pm 1.32$ \\
\hline $5 f$ & $8.81 \pm 1.06$ & 71 & $4.86 \pm 1.56$ \\
\hline $5 \mathrm{~g}$ & $12.4 \pm 0.98$ & $7 \mathrm{~m}$ & $6.84 \pm 1.38$ \\
\hline $5 \mathbf{h}$ & $8.81 \pm 1.15$ & $7 \mathbf{n}$ & $37.04 \pm 1.43$ \\
\hline $5 i$ & $3.93 \pm 1.07$ & 70 & $66.2 \pm 1.55$ \\
\hline $7 \mathbf{a}$ & $39.64 \pm 1.16$ & $7 p$ & $39.64 \pm 1.17$ \\
\hline $7 \mathbf{b}$ & $6.84 \pm 1.31$ & $7 q$ & $76.64 \pm 0.93$ \\
\hline $7 \mathrm{c}$ & $11.03 \pm 1.89$ & $7 \mathbf{r}$ & $47.5 \pm 1.01$ \\
\hline $7 d$ & $13.5 \pm 1.04$ & $7 s$ & $47.49 \pm 1.23$ \\
\hline $7 e$ & $11.03 \pm 1.12$ & $7 t$ & $80.59 \pm 1.19$ \\
\hline $7 f$ & $6.84 \pm 1.29$ & $7 u$ & $66.16 \pm 1.32$ \\
\hline Ascorbic acid & $145.4 \pm 0.27$ & & \\
\hline
\end{tabular}

inhibition of albumin denaturation technique, for the determination of $\mathrm{IC}_{50}$ values (concentration of an inhibitor where the response (or binding) is reduced by half). The results of the activity were compared with the standard drug aspirin. The $\mathrm{IC}_{50}$ values are listed in Table 4 . The synthesized compounds have $\mathrm{IC}_{50}$ values in the micromolar range, varying from 77.11 to 172.04. Among them, ten compounds 5a, 5b, 5d, 5e, 7g, 7h, 7j, 7l, $7 \mathbf{n}$ and $7 \mathbf{q}$ with $\mathrm{IC}_{50}$ values varying from 77.11 to $116.10 \mu \mathrm{M}$ possess relatively better inhibitory efficiency compared to that of standard aspirin $\left(\mathrm{IC}_{50}=116.48 \mu \mathrm{M}\right)$.

\subsubsection{Anti oxidant studies}

2.2.2.1 DPPH radical-scavenging assay. The DPPH (2,2diphenyl-1-picrylhydrazyl) radical-scavenging assay is usually used to evaluate the abilities of new compounds to capture free radicals by producing the reduced form DPPH-H through a hydrogen-donating action. It was performed in order to determine the antioxidant potential. ${ }^{27}$

DPPH is a stable nitrogen-centered free radical. Its reaction rates correlate directly with antioxidant activity, the higher the rate, the more effective the antioxidant. ${ }^{28} \mathrm{~A}$ freshly prepared DPPH solution shows a deep purple color with an absorption maximum at $517 \mathrm{~nm}$. When the purple color changes to yellow, it leads to decreased absorbance. This is because of the antioxidant molecule reducing the DPPH free radical through donation of hydrogen atom. Instantaneous or concomitant decrease in absorbance would be indicative of potent antioxidant activity by the compound. ${ }^{29}$

In this study, we investigated the antioxidant properties of spirofurochromanone derivatives using DPPH scavenging activity with respect to the standard ascorbic acid and using a spectrometric assay.

2.2.2.2 Hydrogen peroxide scavenging assay. Several reactive species are known to produce in excess during the inflammatory processes, the ROS peroxyl radical ( $\mathrm{ROO}^{\circ}$ ), $\mathrm{HO}^{\circ}, \mathrm{O}_{2}{ }^{--}$, $\mathrm{H}_{2} \mathrm{O}_{2}$, and $\mathrm{HOCl}$ play important roles in their pathophysiological conditions, hydrogen peroxide $\left(\mathrm{H}_{2} \mathrm{O}_{2}\right)$ is a biologically important, non-radical reactive oxygen species (ROS) that can influence several cellular processes, which makes them potential targets for the therapy of inflammation. ${ }^{30}$ In vitro antioxidant activities of synthesized compounds were evaluated against hydrogen peroxide and were compared with standard ascorbic acid. Our results reveal that these compounds exhibit better radical scavenging activities. The results of antioxidant activity of spirofurochromanone are shown in Table 6.

\subsubsection{SAR studies}

2.2.3.1 Anti-inflammatory activity. In the series of compounds 5a-i cyclohexylspiro compounds exhibited mild

Table 6 Antioxidant $\mathrm{H}_{2} \mathrm{O}_{2}$ activity of compounds $5 \mathrm{a}-\mathrm{i}$ and $7 \mathrm{a}-\mathrm{u}$

\begin{tabular}{|c|c|c|c|c|}
\hline S. no. & Compound & $\begin{array}{l}\mathrm{IC}_{50}{ }^{a} \text { value } \\
\left(\mu \mathrm{g} \mathrm{mL} \mathrm{mL}^{-1}\right)\end{array}$ & Compound & 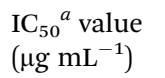 \\
\hline 1 & $5 \mathbf{a}$ & $112.05 \pm 0.88$ & $7 \mathrm{~g}$ & $96.65 \pm 0.79$ \\
\hline 2 & $5 \mathbf{b}$ & $73.67 \pm 0.15$ & $7 \mathrm{~h}$ & $44.73 \pm 0.49$ \\
\hline 3 & $5 c$ & $25.12 \pm 0.26$ & $7 \mathbf{i}$ & $42.26 \pm 0.41$ \\
\hline 4 & $5 d$ & $83.14 \pm 0.13$ & $7 \mathbf{j}$ & $80.05 \pm 0.16$ \\
\hline 5 & $5 e$ & $98.55 \pm 0.18$ & $7 \mathbf{k}$ & $42.26 \pm 0.41$ \\
\hline 6 & $5 f$ & $41.11 \pm 1.23$ & 71 & $82.21 \pm 0.61$ \\
\hline 7 & $5 g$ & $68.6 \pm 0.54$ & $7 \mathrm{~m}$ & $78.05 \pm 0.65$ \\
\hline 8 & $5 h$ & $77.05 \pm 0.34$ & $7 n$ & $43.04 \pm 0.50$ \\
\hline 9 & $5 \mathbf{i}$ & $51.42 \pm 0.69$ & 70 & $49.51 \pm 0.17$ \\
\hline 10 & $7 a$ & $103.95 \pm 0.9$ & $7 p$ & $93.12 \pm 0.23$ \\
\hline 11 & $7 \mathbf{b}$ & $70.93 \pm 0.38$ & $7 q$ & $35.51 \pm 0.07$ \\
\hline 12 & $7 \mathrm{c}$ & $32.11 \pm 0.38$ & $7 \mathbf{r}$ & $35.51 \pm 0.07$ \\
\hline 13 & $7 d$ & $62.05 \pm 0.74$ & $7 \mathrm{~s}$ & $62.03 \pm 0.77$ \\
\hline 14 & $7 e$ & $51.21 \pm 0.35$ & $7 t$ & $78.05 \pm 0.22$ \\
\hline \multirow[t]{2}{*}{15} & $7 f$ & $37.11 \pm 0.41$ & $7 \mathbf{u}$ & $76.5 \pm 0.24$ \\
\hline & & & Ascorbic acid & $77.13 \pm 0.87$ \\
\hline
\end{tabular}

${ }^{a}$ Values are mean \pm SD of three replicates. 
Table 7 Dock score of molecules at different binding site in BSA

\begin{tabular}{|c|c|c|c|c|c|}
\hline \multirow[b]{2}{*}{ Molecule } & \multicolumn{5}{|c|}{ Dock score in kcal mol${ }^{-1}$} \\
\hline & Site 1 & Site 2 & Site 3 & Site 4 & Site 5 \\
\hline $5 \mathbf{a}$ & -5.04465 & -3.76925 & -3.22027 & -1.97144 & -5.34381 \\
\hline $5 \mathbf{b}$ & -4.91124 & -3.69292 & -2.36801 & -1.32099 & -6.55207 \\
\hline $5 \mathrm{c}$ & -5.17773 & -3.79194 & -3.39834 & 0.802319 & -6.12478 \\
\hline $5 d$ & -5.14163 & -4.0252 & -2.04788 & 0.990484 & -6.02642 \\
\hline $5 e$ & -4.25431 & -3.73157 & -2.89809 & -1.93373 & -4.97476 \\
\hline $5 f$ & -5.33577 & -3.83444 & -3.39073 & 0.022163 & -5.15616 \\
\hline $5 \mathrm{~g}$ & -6.90317 & -3.67625 & -2.97721 & 1.069312 & -5.77175 \\
\hline $5 \mathrm{~h}$ & -4.28098 & -3.25556 & -3.15456 & 0.50295 & -6.799 \\
\hline $5 \mathbf{i}$ & -6.28092 & -3.9708 & -3.3511 & -0.73673 & -6.35011 \\
\hline $7 \mathbf{a}$ & -5.66842 & -4.50547 & -3.2195 & -2.63023 & -6.64511 \\
\hline $7 \mathbf{b}$ & -5.24438 & -3.09017 & -3.44921 & -0.71678 & -7.00437 \\
\hline $7 \mathrm{c}$ & -5.91122 & -3.45821 & -2.0643 & -2.46974 & -7.34291 \\
\hline $7 d$ & -5.85966 & -3.22219 & -1.79908 & -1.40511 & -6.77104 \\
\hline $7 e$ & -7.25977 & -4.21203 & 0.528595 & -2.32848 & -6.20783 \\
\hline $7 \mathrm{f}$ & -6.07993 & -3.94704 & -1.57723 & -3.23294 & -6.81214 \\
\hline $7 \mathrm{~g}$ & -6.13347 & -4.7289 & -3.18466 & 1.503116 & -7.29907 \\
\hline $7 \mathrm{~h}$ & -6.74828 & -3.78363 & -3.95033 & -3.43081 & -6.0202 \\
\hline $7 \mathbf{i}$ & -5.42021 & -3.15689 & -2.20818 & -3.40362 & -6.66791 \\
\hline $7 \mathbf{j}$ & -6.89574 & -3.61415 & -2.67466 & -0.57856 & -6.67635 \\
\hline $7 \mathbf{k}$ & -6.17567 & -4.04447 & -1.78585 & -1.43157 & -6.52291 \\
\hline 71 & -6.59588 & -4.43139 & -0.44855 & -2.04492 & -5.46365 \\
\hline $7 \mathrm{~m}$ & -4.5574 & -3.97825 & -1.5371 & -2.85352 & -5.66012 \\
\hline $7 \mathbf{n}$ & -7.01527 & -5.64609 & -1.0642 & -2.98835 & -6.32379 \\
\hline 70 & -5.5679 & -4.59082 & -3.14312 & -0.16728 & -6.54276 \\
\hline $7 p$ & -5.22365 & -2.67248 & -3.32493 & -1.96602 & -6.74707 \\
\hline $7 q$ & -6.75491 & -4.53187 & -2.50503 & -2.28726 & -6.61332 \\
\hline $7 \mathbf{r}$ & -6.02244 & -3.42691 & -3.08999 & -2.80693 & -6.5254 \\
\hline $7 \mathrm{~s}$ & -6.41682 & -3.98382 & -2.45205 & -0.77139 & -6.29255 \\
\hline $7 t$ & -5.87745 & -3.0637 & -3.17249 & -2.34786 & -6.92566 \\
\hline $\mathbf{u}$ & -6.50778 & -4.66838 & -3.28726 & -2.36884 & -6.51469 \\
\hline
\end{tabular}

anti-inflammatory activity, $N$-Bocpiperidinylspiro compound 5b has better activity with $\mathrm{IC}_{50}$ value 77.9 and the activity decreases with the change in the substitution at 4 th carbon of 2'-benzoyl group with bromo (5e, $\mathrm{IC}_{50}$ value 98.4$)$ or chloro (5h, $\mathrm{IC}_{50}$ value 140.4) groups. Among the Suzuki cross coupled products $7 \mathbf{a}-\mathbf{u}, N$-Bocpiperidinylspiro derivatives $7 \mathbf{h}-\mathbf{n}$ show better activity when compared to cyclohexylspiro derivatives $7 \mathbf{a}-\mathbf{g}$ and cyclopentylspiro derivatives $7 \mathbf{0}-\mathbf{u}$. Among $N$-Bocpiperidinylspiro compounds $7 \mathbf{h}\left(\mathrm{IC}_{50}\right.$ value 77.1$)$ exhibited better activity when compared to other substitutions on the biaryl group.

\subsubsection{Antioxidant activity}

2.2.3.2.1 DPPH radical scavenging activity. Compounds $\mathbf{5 a - i}$, showed good antioxidant activity compared with the standard ascorbic acid. Compounds $\mathbf{5 d}$ and $\mathbf{5 i}$ have better activity while $\mathbf{5 a}$, $\mathbf{5 c}, \mathbf{5 f}, \mathbf{5 h}$ have almost same activity. Cyclopentylspiro derivatives 7o-u among the biaryl series of compounds 7a-u show mild antioxidant activity whereas the series of $N$-Bocpiperidinylspiro and cyclohexylspiro compounds exhibit better activity. 7a-g compounds have better $\mathrm{IC}_{50}$ values ranging from 3 to 39 owing to the presence of the substituent on the phenyl group of biaryl compound.

2.2.3.2.2 Hydrogen peroxide scavenging assay. Compounds $\mathbf{5 b}-\mathbf{c}$ and $\mathbf{5 f - i}$, with chlorine and bromine as substituent show better activity as compared with the standard ascorbic acid. Among the Suzuki cross coupled products compared to cyclohexylspiro derivative, $N$-Bocpiperidinylspiro derivative and cyclopentylspiro derivative show better activity without any substituent on the biaryl group. In the series of cyclohexylspiro derivatives $\mathbf{7 b}$-f exhibits better activity out of which presence of chloro group (7c, $\mathrm{IC}_{50}$ value 32.11 and $7 \mathbf{f}, \mathrm{IC}_{50}$ value 37.11$)$ on the biaryl moiety exhibits good activity. Among $N$-Bocpiperidinylspiro derivatives biaryl moieties with $\mathrm{CHO}$, Me and $\mathrm{F}$ as substituents exhibit good activity (7i, IC $\mathrm{IC}_{50}$ value $42.26,7 \mathbf{k} \mathrm{IC}_{50}$ value $42.26,7 \mathbf{n}$ $\mathrm{IC}_{50}$ value 43.04 respectively). Chloro and methyl substituents on the biaryl groups of the cyclopentylspiro derivatives exhibit good activity ( $7 \mathbf{q ~ I C}$ I0 value 35.51 and $7 \mathbf{r}$ IC $_{50}$ value 35.51$)$.

Table 8 Dock score of molecules in bovine serum albumin site-1, site-5 and COX-2

\begin{tabular}{|c|c|c|c|c|c|c|c|}
\hline \multirow{2}{*}{ Molecule } & \multicolumn{3}{|c|}{ Dock score in kcal mol ${ }^{-1}$} & \multirow{2}{*}{ Molecule } & \multicolumn{3}{|c|}{ Dock score in kcal mol ${ }^{-1}$} \\
\hline & \multicolumn{2}{|l|}{ BSA } & $\mathrm{COX}-2$ & & \multicolumn{2}{|l|}{ BSA } & COX-2 \\
\hline $5 \mathbf{a}$ & -5.044 & -5.343 & -8.415 & $7 \mathrm{~g}$ & -6.133 & -7.299 & -9.378 \\
\hline $5 \mathbf{b}$ & -4.911 & -6.552 & -9.807 & $7 \mathbf{h}$ & -6.748 & -6.020 & -9.549 \\
\hline $5 e$ & -4.254 & -4.974 & -8.998 & $7 \mathbf{k}$ & -6.17567 & -6.522 & -5.329 \\
\hline $5 f$ & -5.335 & -5.156 & -7.424 & 71 & -6.59588 & -5.463 & -5.522 \\
\hline $5 \mathrm{~g}$ & -6.903 & -5.771 & -7.689 & $7 \mathbf{m}$ & -4.5574 & -5.660 & -9.519 \\
\hline $5 \mathbf{h}$ & -4.280 & -6.799 & -7.055 & $7 n$ & -7.01527 & -6.323 & -5.839 \\
\hline $5 \mathbf{i}$ & -6.280 & -6.350 & -6.919 & 70 & -5.5679 & -6.542 & -8.001 \\
\hline $7 a$ & -5.668 & -6.645 & -7.839 & $7 \mathbf{p}$ & -5.22365 & -6.747 & -8.249 \\
\hline $7 f$ & -6.079 & -6.812 & -4.634 & $7 \mathbf{u}$ & -6.50778 & -6.514 & -9.276 \\
\hline
\end{tabular}


a

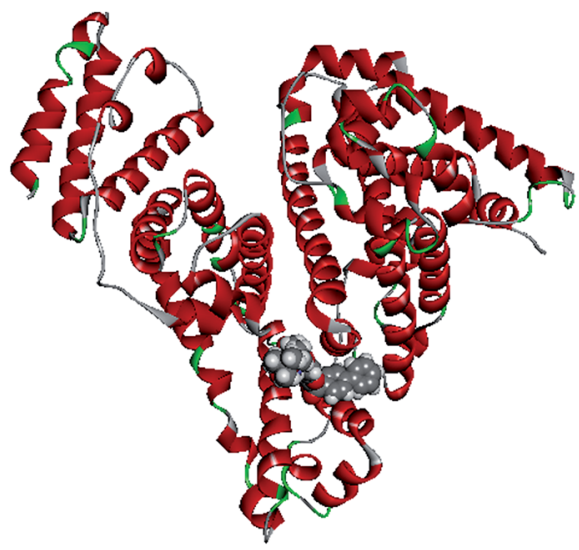

b

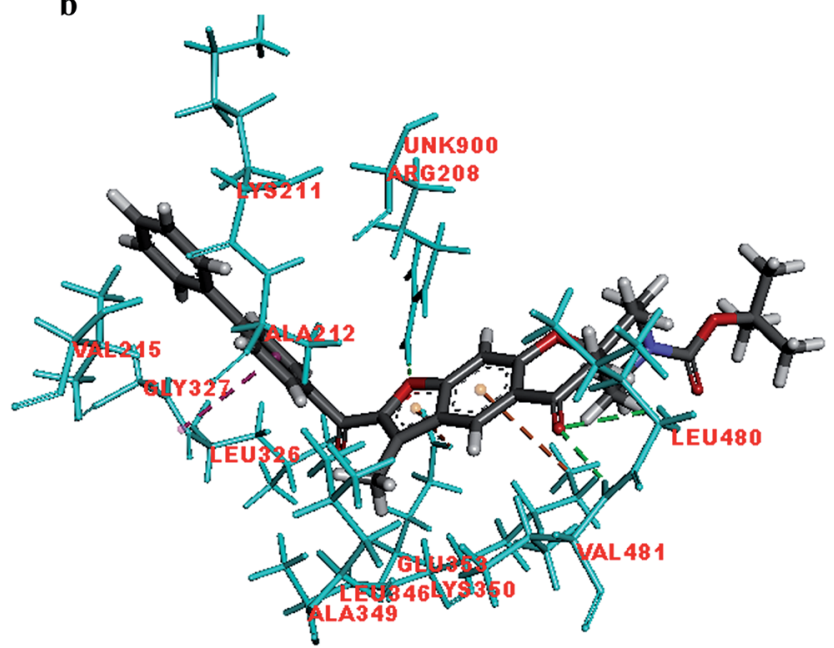

Fig. 2 (a) Molecule $7 \mathrm{~h}$ docked at site-5 of BSA. (b) Molecular interaction of molecule $7 \mathrm{~h}$ showing hydrogen bond interaction with Leu 480, Val 481 and Arg 208, electrostatic interaction with Lys 350 and Glu 353. a

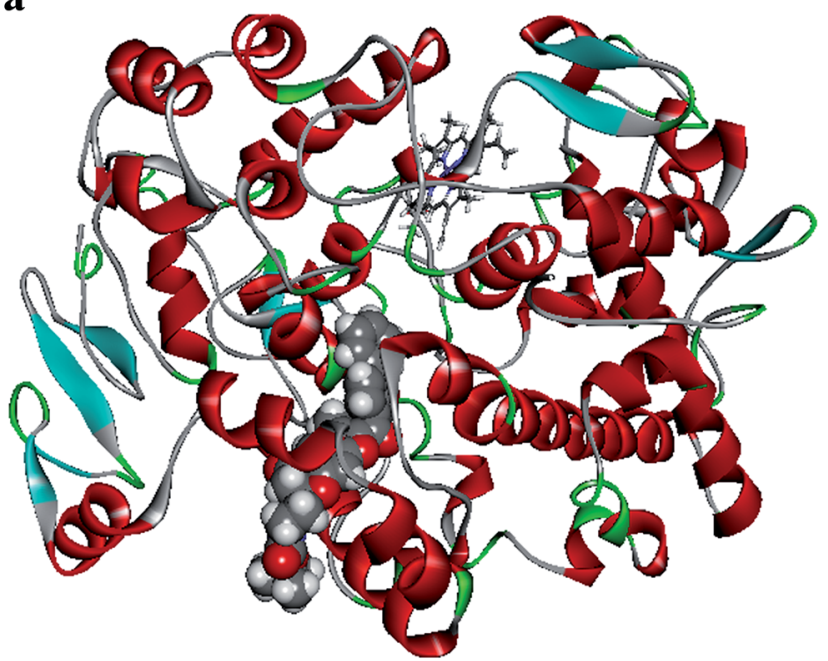

b

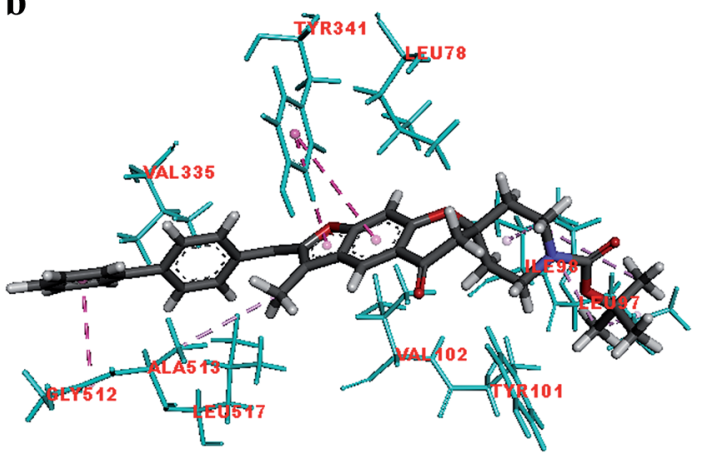

UNK900

Fig. 4 (a) Molecule 7h docked at active site of COX-2. (b) Molecular interaction of molecule $7 \mathrm{~h}$ showing $\pi-\pi$ interaction with Tyr 341 and hydrophobic interaction Gly 512 and Ala 513

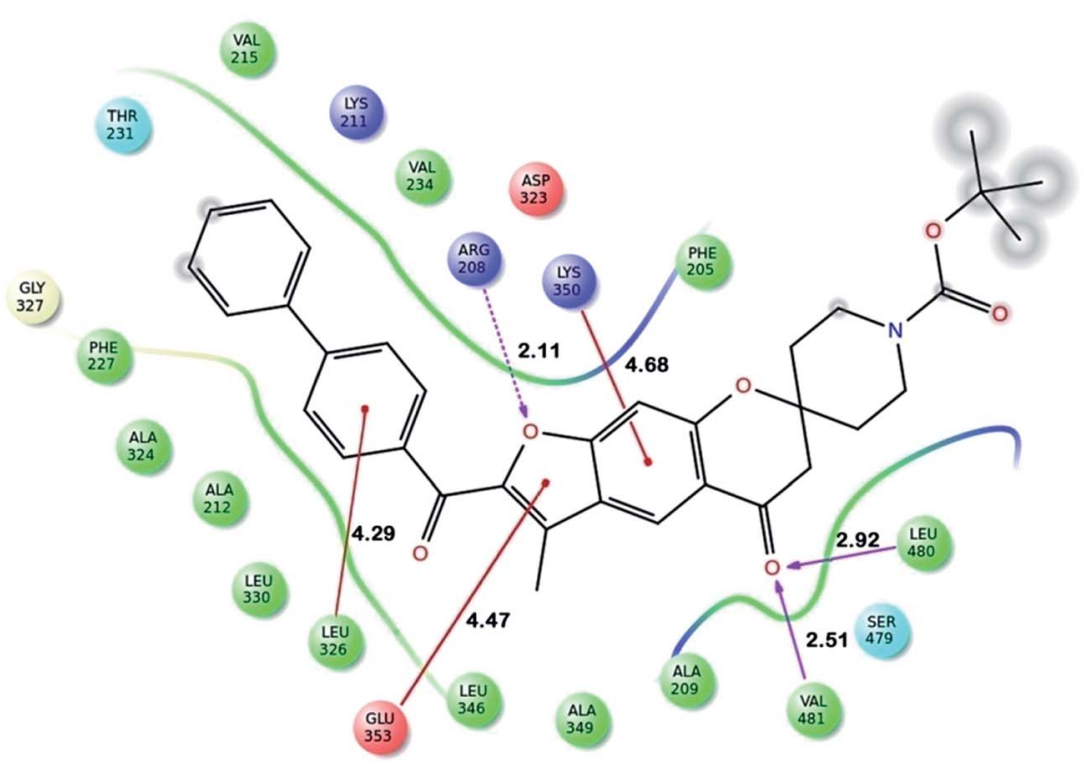

Fig. 3 Ligand interaction diagram of molecule 7h docked at site- 5 of BSA showing hydrogen bond interaction with Leu 480, Val 481 and Arg 208 , electrostatic interaction with Lys 350 and Glu 353 [distance are mentioned in Å]. 
Table 9 ADME properties of molecule

\begin{tabular}{|c|c|c|c|c|c|}
\hline Molecule & $\begin{array}{l}\mathrm{QP} \\
\log P_{\mathrm{O} / \mathrm{w}}{ }^{a}\end{array}$ & $\begin{array}{l}\text { QP } \\
\log S^{b}\end{array}$ & $\begin{array}{l}\mathrm{QP} \\
\log \mathrm{BB}^{c}\end{array}$ & $\mathrm{QP}_{\mathrm{PMDCK}}{ }^{d}$ & $\begin{array}{l}\text { Percent } \\
\text { human oral } \\
\text { absorption }\end{array}$ \\
\hline $5 \mathbf{a}$ & 4.022 & -5.314 & -0.453 & 643.955 & 100 \\
\hline $5 b$ & 4.601 & -6.753 & -0.995 & 280.644 & 100 \\
\hline $5 c$ & 3.756 & -4.981 & -0.46 & 616.566 & 100 \\
\hline $5 d$ & 4.604 & -6.194 & -0.289 & 1709.413 & 100 \\
\hline $5 e$ & 5.19 & -7.652 & -0.841 & 744.903 & 81.033 \\
\hline $5 f$ & 4.309 & -5.807 & -0.285 & 1679.254 & 100 \\
\hline $5 g$ & 4.528 & -6.082 & -0.299 & 1589.697 & 100 \\
\hline $5 \mathrm{~h}$ & 5.111 & -7.531 & -0.849 & 692.753 & 80.568 \\
\hline $5 i$ & 4.23 & -5.687 & -0.294 & 1561.757 & 100 \\
\hline $7 a$ & 5.711 & -7.481 & -0.612 & 643.259 & 100 \\
\hline $7 \mathbf{b}$ & 4.579 & -6.945 & -1.543 & 103.589 & 96.205 \\
\hline $7 c$ & 6.212 & -8.234 & -0.456 & 1588.787 & 100 \\
\hline $7 d$ & 6.033 & -8.079 & -0.638 & 643.102 & 100 \\
\hline $7 e$ & 6.65 & -8.631 & -0.646 & 642.485 & 95.54 \\
\hline $7 f$ & 6.721 & -9.017 & -0.302 & 3911.802 & 95.966 \\
\hline $7 \mathrm{~g}$ & 5.951 & -7.857 & -0.505 & 1164.676 & 100 \\
\hline $7 \mathbf{h}$ & 6.285 & -8.904 & -1.183 & 280.243 & 87.434 \\
\hline $7 \mathbf{i}$ & 5.149 & -8.358 & -2.202 & 45.132 & 67.651 \\
\hline $7 \mathbf{j}$ & 6.795 & -9.687 & -1.036 & 692.527 & 90.425 \\
\hline $7 \mathbf{k}$ & 6.612 & -9.519 & -1.219 & 280.159 & 89.347 \\
\hline 71 & 7.236 & -10.104 & -1.234 & 280.245 & 93.003 \\
\hline $7 \mathrm{~m}$ & 7.295 & -10.439 & -0.886 & 1704.24 & 93.351 \\
\hline $7 \mathbf{n}$ & 6.525 & -9.28 & -1.078 & 507.476 & 88.843 \\
\hline 70 & 5.448 & -7.157 & -0.623 & 615.852 & 100 \\
\hline $7 \mathbf{p}$ & 4.316 & -6.621 & -1.547 & 99.175 & 94.352 \\
\hline $7 q$ & 5.954 & -7.926 & -0.468 & 1521.395 & 100 \\
\hline $7 \mathbf{r}$ & 5.775 & -7.772 & -0.651 & 615.837 & 100 \\
\hline $7 s$ & 6.387 & -8.307 & -0.657 & 615.107 & 100 \\
\hline $7 t$ & 6.418 & -8.605 & -0.297 & 3842.145 & 94.06 \\
\hline $7 \mathbf{u}$ & 5.688 & -7.533 & -0.516 & 1115.143 & 100 \\
\hline
\end{tabular}

${ }^{a}$ Predicted octanol/water partition coefficient $\log P$ (acceptable range-2.06.5). ${ }^{b}$ Predicted aqueous solubility in $\mathrm{mol} \mathrm{L}^{-1}$ (acceptable range-6.5-0.5). ${ }^{c}$ Predicted blood brain barrier permeability (acceptable range-3-1.2).

${ }^{d}$ Predicted apparent MDCK cell permeability in $\mathrm{nm} \mathrm{s}^{-1}$ (acceptable range in $\mathrm{nm} \mathrm{s}^{-1}$ ) (acceptable range: $<25$ is poor and $>500$ is great). ${ }^{e}$ Percentage of human oral absorption (acceptable range: $<25$ is poor and $>80 \%$ is high).

\subsection{Molecular docking analysis}

BSA consists of 583 amino acid residues present in three homologous $\alpha$-helical domains (I, II, III). Each domain comprises sub-domain A and sub-domain B. Subdomains IIA, IIIA and IB among them are known as Sudlow's site I, II and III, respectively (ESI). ${ }^{31-33}$ To determine the binding interaction of the molecules with bovine serum albumin molecular docking analysis was performed on five binding cavities obtained from site map. Analysis of dock score reveals that the binding affinity of these molecules is more towards the site- 5 and site- 1 as compared to the other hydrophobic cavities, site- 5 and site- 1 correspond to drug binding site I and site II. ${ }^{31-39}$ Dock score of molecules at site- 5 and site- 1 along with the dock score of the molecules which were docked into COX-2 (one of the target for anti-inflammatory) to check the possible mode of interaction is provided in Table 8 (the dock score for molecules at all site is provided in Table 7). Binding energy of the molecules at site- 5 ranged between -7.342 to $-4.974 \mathrm{kcal} \mathrm{mol}^{-1}$, and for site-1 it ranged between -7.259 to $-4.254 \mathrm{kcal} \mathrm{mol}^{-1}$ few molecules showed lower and positive binding energies at site-2, site-3 and site-4.

Fig. 2 shows the interaction of molecule $7 \mathrm{~h}$ with protein at site- 5 . The molecule showed three hydrogen bond interactions with amino acid residues Leu 480, Val 481 and Arg 208. Two electrostatic interactions were also seen between the $\pi$ electron cloud of fused aromatic ring and residues Lys 350 and Glu 353. A hydrophobic interaction is also seen with Leu 326. Fig. 3 represents the hydrogen bond interaction with Leu 480, Val 481, Arg 208 and electrostatic interaction with Lys 350, Glu 353 of molecule $7 \mathrm{~h}$ at site- 5 of BSA. Fig. 4 represents the docked conformation of molecule $7 \mathbf{h}$ showing $\pi-\pi$ interaction with Tyr 341 and hydrophobic interaction Gly 512 and Ala 513 at active site of COX-2. Fig. 5 shows the ligand $\pi-\pi$ interaction with Tyr 341 and hydrophobic interaction with Gly 512, Ala 513 of molecule $\mathbf{7 h}$ docked at active site of COX-2.

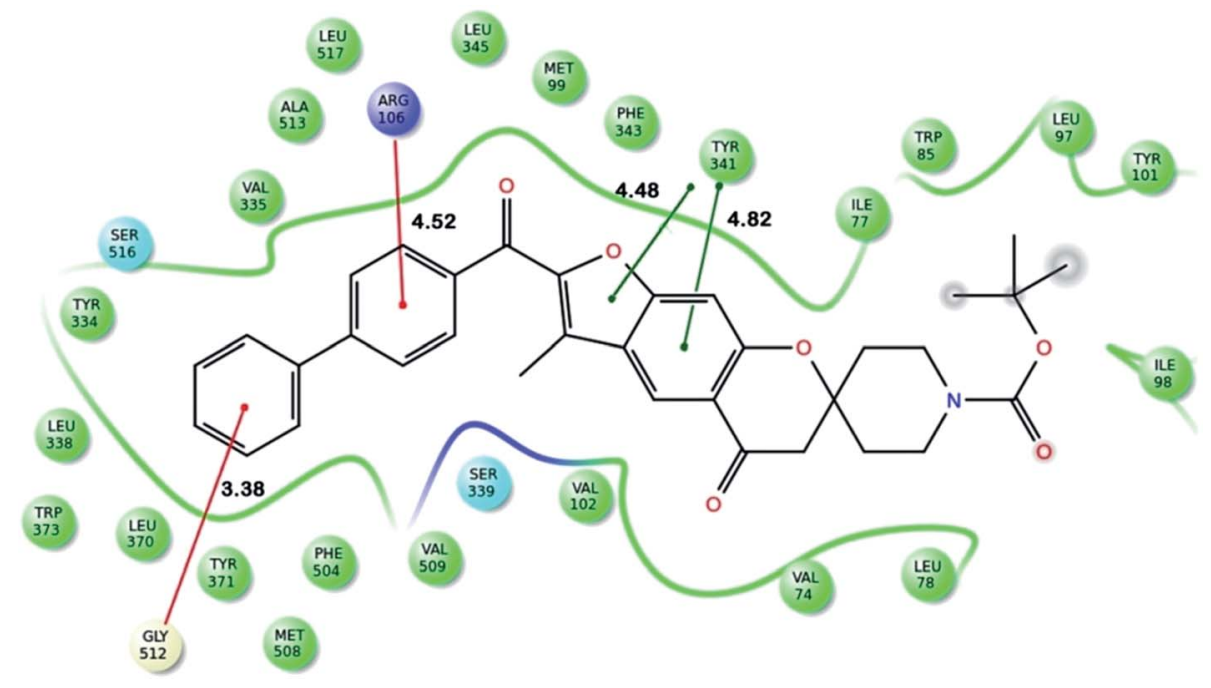

Fig. 5 Ligand interaction diagram of molecule $7 \mathrm{~h}$ docked at active site of COX-2 showing $\pi-\pi$ interaction with Tyr 341 and hydrophobic interaction Arg 106, Gly 512 and Ala 513 [distance are mentioned in Å]. 
2.3.1 ADME properties. The ADME properties (required pharmacokinetic properties of viable drug compounds) were calculated by Qikprop and analyzed by applying Lipinski's rule of five (Table 9). ${ }^{40}$ Molecular weight less than 650, partition coefficient between octanol and water $\left(\log P_{\mathrm{o} / \mathrm{w}}\right)$ between -1 and 6.5 and solubility $(\log S)$ greater than -7 . Pmdck greater than 5 and $\log$ BB greater than -3 , these parameter tells us about the ability of the drug to pass through blood brain barrier. Majority of the molecules have the properties in range, partition coefficient of molecules ranged within the acceptable limits expect for two molecules $\mathbf{7 l}$ and $\mathbf{7 m}$ that had values greater than 7 . Cell permeability and blood brain barrier permeability for all molecules is in permissible range. Water solubility and oral absorption for half of the molecules is $100 \%$. The values invariably imply that these molecules are potential drug molecules and can be further optimized for better activity (Fig. 5).

\section{Conclusion}

In conclusion, we herein report the selective synthesis of monospiro chromanone derivatives $\mathbf{3 a}-\mathbf{c}$ from which a series of spirofurochromanones were synthesized following microwave irradiation method and their anti-inflammatory and antioxidant activities were determined. The reaction protocol requires cheap starting materials and is carried out under mild conditions. Compounds $5 \mathbf{a}, \mathbf{5 b}, \mathbf{5 c}, \mathbf{5 d}, \mathbf{5 e}, \mathbf{7 g}, \mathbf{7 h}, \mathbf{7 j}, \mathbf{7 l}, \mathbf{7 n}$ and $\mathbf{7 q}$ were found to be promising with $\mathrm{IC}_{50}$ values ranging from 77.11 to $116.10 \mu \mathrm{M} \mathrm{mL} L^{-1}$ indicates that they are potential antiinflammatory agents. The binding mode of the synthesized compounds with protein active site was predicted using in silico docking. All the compounds $5 \mathbf{a}-\mathbf{i}$ and $7 \mathbf{a}-\mathbf{u}$ were docked well into the binding pocket of the target protein at all the five sites. The compounds showed good docking at site I and site V.

\section{Experimental section}

\subsection{General methods}

All the Suzuki reactions were performed under nitrogen atmosphere using oven dried apparatus. Reactions were monitored by thin layer chromatography (TLC) on silica gel plates $\left(60 \mathrm{~F}_{254}\right)$, visualizing with ultraviolet light. Column chromatography was performed on silica gel (60-120 mesh) using distilled hexane, ethyl acetate. ${ }^{1} \mathrm{H}$ NMR and ${ }^{13} \mathrm{C}$ NMR spectra were determined in $\mathrm{CDCl}_{3}$ solution by using 400 and $100 \mathrm{MHz}$ spectrometers, respectively (Instrument Bruker Avance II $400 \mathrm{MHz}$ ). Proton chemical shifts $(\delta)$ are relative to tetramethylsilane (TMS, $\delta=$ 0.00 ) as internal standard and expressed in ppm. Spin multiplicities are given as s (singlet), $d$ (doublet), $t$ (triplet), q (quartet) and $\mathrm{m}$ (multiplet) as well as bs (broad singlet). Coupling constants $(J)$ are given in hertz. Mass spectra were recorded on GCMS-QP 1000 EX mass spectrometer. Infrared spectra were recorded on a Shimadzu FT-IR-8400s spectrometer. Melting points were determined using Stuart SMP3 melting-point apparatus and are uncorrected. CEM discover microwave reaction vessel equipped with a magnetic stirrer was used for microwave irradiated reactions. The antioxidant property was carried out by using Shimadzu UV-2450 spectrophotometer and the Perkin Elmer Lambda 750 UV-Visible Spectrophotometer was used to calculate the percentage inhibition for anti inflammatory activity. Bovine serum albumin used for the antiinflammatory activity was purchased from Sigma Aldrich.

\subsection{General experimental procedure $3 a-c$}

A solution of compound 1 ( $1 \mathrm{mmol})$ and pyrrolidine $(1 \mathrm{mmol})$ in toluene was refluxed for $10 \mathrm{~min}$. To the above solution various cycloalkanones $2 \mathrm{a}-\mathbf{c}(1.5 \mathrm{mmol})$ were added and the reaction mixture was stirred at $90{ }^{\circ} \mathrm{C}$ for $4 \mathrm{~h}$, the completion of reaction was monitored by TLC. Compound from the resulting solution was precipitated using $15 \% \mathrm{NaOH}$ solution, the precipitate was filtered, solid was neutralized with dil. $\mathrm{HCl}$ and washed with water, dried in air and recrystallised from ethanol to afford pure monospiro compound 3a-c.

4.2.1 6-Acetyl-7-hydroxyspiro[chroman-2,1'-cyclopentan]-4one (3c). White solid; M.F: $\mathrm{C}_{16} \mathrm{H}_{18} \mathrm{O}_{4}$; mp: $132-134{ }^{\circ} \mathrm{C}$; yield: $40 \%$; IR ( $\left.\mathrm{KBr}, \mathrm{cm}^{-1}\right): 3282,2935,1629,1608,1225 ;{ }^{1} \mathrm{H}$ NMR (400 $\left.\mathrm{MHz}, \mathrm{CDCl}_{3}\right) \delta 12.82(\mathrm{~s}, 1 \mathrm{H}), 8.37(\mathrm{~s}, 1 \mathrm{H}), 6.40(\mathrm{~s}, 1 \mathrm{H}), 2.82(\mathrm{~s}$, $2 \mathrm{H}), 2.63(\mathrm{~s}, 3 \mathrm{H}), 2.11-2.05(\mathrm{~m}, 2 \mathrm{H}), 1.92-1.84(\mathrm{~m}, 2 \mathrm{H}), 1.78-1.64$ $(\mathrm{m}, 4 \mathrm{H}) ;{ }^{13} \mathrm{C}$ NMR $\left(100 \mathrm{MHz}, \mathrm{CDCl}_{3}\right) \delta 203.6,190.4,168.4,165.7$, 132.0, 115.0, 114.0, 105.2, 91.0, 46.6, 37.6, 26.3, 23.7; MS (ESI mass): $m / z, 261[\mathrm{M}+\mathrm{H}]^{+}$.

\subsection{General experimental procedure 5a-i}

4.3.1 Conventional method. A solution of monospiro compound 3a-c (1 mmol), substituted phenacyl bromide $4 \mathbf{a}-\mathbf{c}$ $(1 \mathrm{mmol})$ and anhydrous $\mathrm{K}_{2} \mathrm{CO}_{3}(3 \mathrm{mmol})$ in dry acetone were stirred at $60{ }^{\circ} \mathrm{C}$ for $3 \mathrm{~h}$, the completion of reaction was monitored by TLC. The resulting solution was diluted with water and the precipitate formed was filtered, washed with water, dried in air and was purified by column chromatography (using 5-10\% petroleum ether/ethyl acetate) to afford desired compound $\mathbf{5 a - i}$.

4.3.2 Microwave method. Monospiro compound 3a-c (1 mmol), substituted phenacyl bromide $4 \mathbf{a}-\mathbf{c}(1 \mathrm{mmol})$ was dissolved in acetone and adsorbed over $\mathrm{K}_{2} \mathrm{CO}_{3}$. This mixture was microwave irradiated at $100 \mathrm{~W}$ for $5 \mathrm{~min}$. The resultant mixture was diluted with water. The solid formed was filtered, washed with water, dried in air and purified by column chromatography (using $5-10 \%$ petroleum ether/ethyl acetate) to afford desired compound $\mathbf{5 a}-\mathbf{i}$.

4.3.2.1 2'-Benzoyl-3'-methylspiro[cyclohexane-1,7'-furo[3,2-g] chromen]-5' ( $\left.6^{\prime} H\right)$-one (5a). White solid; M.F: $\mathrm{C}_{24} \mathrm{H}_{22} \mathrm{O}_{4}$; mp: 128$130{ }^{\circ} \mathrm{C}$; yield: $82 \%$; IR $\left(\mathrm{KBr}, \mathrm{cm}^{-1}\right)$ : 3082, 2931, 1649, 1618, 1475; ${ }^{1} \mathrm{H}$ NMR (400 MHz, $\mathrm{CDCl}_{3}$ ) $\delta 8.27(\mathrm{~s}, 1 \mathrm{H}), 8.04-8.02(\mathrm{~d}, J=$ $7.0 \mathrm{~Hz}, 2 \mathrm{H}), 7.63-7.59(\mathrm{t}, J=7.0 \mathrm{~Hz}, 1 \mathrm{H}), 7.52-7.50(\mathrm{t}, J=7.0 \mathrm{~Hz}$, $2 \mathrm{H}), 7.07(\mathrm{~s}, 1 \mathrm{H}), 2.77(\mathrm{~s}, 2 \mathrm{H}), 2.59(\mathrm{~s}, 3 \mathrm{H}), 2.03-2.01(\mathrm{~m}, 2 \mathrm{H})$, 1.75-1.68 (m, 2H), 1.56-1.51 (m, 6H); ${ }^{13} \mathrm{C}$ NMR (100 MHz, $\left.\mathrm{CDCl}_{3}\right) \delta 192.1,185.3,160.0,158.9,149.0,137.7,132.6,129.5$, 128.3, 127.7, 124.0, 120.9, 118.9, 100.5, 80.6, 48.3, 34.9, 25.1, 21.4, 10.0; MS (ESI mass): $m / z, 375[\mathrm{M}+\mathrm{H}]^{+}$.

4.3.2.2 tert-Butyl-7-benzoyl-6-methyl-4-oxo-4,8-dihydro-3Hspiro[cyclopenta[g]chromene-2,4'-piperidine]-1'-carboxylate (5b). White solid; M.F: $\mathrm{C}_{28} \mathrm{H}_{29} \mathrm{NO}_{6}$; mp: $220-222{ }^{\circ} \mathrm{C}$; yield: $84 \%$; IR $\left(\mathrm{KBr}, \mathrm{cm}^{-1}\right): 2972,1683,1620,1246,1153 ;{ }^{1} \mathrm{H}$ NMR $(400 \mathrm{MHz}$, $\left.\mathrm{CDCl}_{3}\right) \delta 8.30(\mathrm{~s}, 1 \mathrm{H}), 8.04-8.02(\mathrm{~d}, J=7.5 \mathrm{~Hz}, 2 \mathrm{H}), 7.63-7.61(\mathrm{t}, J$ 
$=7.5 \mathrm{~Hz}, 1 \mathrm{H}), 7.54-7.50(\mathrm{t}, J=7.5 \mathrm{~Hz}, 2 \mathrm{H}), 7.10(\mathrm{~s}, 1 \mathrm{H}), 3.88(\mathrm{bs}$, $2 \mathrm{H}), 3.24$ (bs, 2H), $2.79(\mathrm{~s}, 2 \mathrm{H}), 2.60(\mathrm{~s}, 3 \mathrm{H}), 2.02-2.06(\mathrm{~m}, 2 \mathrm{H})$, 1.69-1.62 (m, 2H), $1.46(\mathrm{~s}, 9 \mathrm{H}) ;{ }^{13} \mathrm{C} \mathrm{NMR} \mathrm{(100} \mathrm{MHz,} \mathrm{CDCl}_{3}$ ) $\delta 191.0,185.2,159.3,158.9,154.6,149.2,137.6,132.7,129.5$, $128.3,127.5,124.5,121.1,118.7,100.6,79.8,78.5,48.1,34.1$, 28.4, 9.9; MS (EI mass): $m / z, 475[\mathrm{M}]^{+}$.

4.3.2.3 2'-Benzoyl-3'-methylspiro[cyclopentane-1,7'-furo[3,2-g] chromen]-5'(6'H)-one (5c). White solid; M.F: $\mathrm{C}_{23} \mathrm{H}_{20} \mathrm{O}_{4}$; mp: 68$70{ }^{\circ} \mathrm{C}$; yield: 71\%; IR (KBr, $\left.\mathrm{cm}^{-1}\right): 2982,1687,1618,1230,1145$; ${ }^{1} \mathrm{H}$ NMR (400 MHz, $\left.\mathrm{CDCl}_{3}\right) \delta 8.29(\mathrm{~s}, 1 \mathrm{H}), 8.04-8.02(\mathrm{~d}, J=$ $8.5 \mathrm{~Hz}, 2 \mathrm{H}), 7.63-7.59(\mathrm{~m}, J=8.5 \mathrm{~Hz}, 1 \mathrm{H}), 7.54-7.50(\mathrm{t}, J=$ $8.5 \mathrm{~Hz}, 2 \mathrm{H}), 7.02(\mathrm{~s}, 1 \mathrm{H}), 2.90(\mathrm{~s}, 2 \mathrm{H}), 2.59(\mathrm{~s}, 3 \mathrm{H}), 2.13-2.08(\mathrm{~m}$, $2 \mathrm{H}), 1.93-1.87(\mathrm{~m}, 2 \mathrm{H}), 1.77-1.66(\mathrm{~m}, 4 \mathrm{H})$; MS (ESI mass): $m / z$, $361[\mathrm{M}+\mathrm{H}]^{+}$.

4.3.2.4 2'-(4-Bromobenzoyl)-3'-methylspiro[cyclohexane-1, $7^{\prime}$ furo[3,2-g]chromen]-5'(6'H)-one (5d). White solid; M.F: $\mathrm{C}_{24} \mathrm{H}_{21} \mathrm{BrO}_{4}$; mp: $148-150{ }^{\circ} \mathrm{C}$; yield: $83 \%$; IR $\left(\mathrm{KBr}, \mathrm{cm}^{-1}\right): 3265$, 2927, 1689, 1620, 1336, 1244; ${ }^{1} \mathrm{H}$ NMR (400 MHz, $\left.\mathrm{CDCl}_{3}\right) \delta 8.28$ (s, 1H), 7.95-7.93 (d, $J=8.5 \mathrm{~Hz}, 2 \mathrm{H}), 7.67-7.65(\mathrm{~d}, J=8.5 \mathrm{~Hz}$, $2 \mathrm{H}), 7.07$ (s, 1H), $2.77(\mathrm{~s}, 2 \mathrm{H}), 2.62(\mathrm{~s}, 3 \mathrm{H}), 1.75-1.64(\mathrm{~m}, 3 \mathrm{H})$, 1.57-1.51 (m, 7H); ${ }^{13} \mathrm{C}$ NMR (100 MHz, $\left.\mathrm{CDCl}_{3}\right) \delta 192.1,183.9$, 160.2 , 158.8, 148.7, 136.3, 131.1, 128.4, 127.8, 123.9, 121.0, 119.0, 100.5, 80.7, 48.2, 34.9, 25.0, 21.4, 10.0; MS (ESI mass): $m /$ $z, 453[\mathrm{M}+\mathrm{H}]^{+}$.

4.3.2.5 tert-Butyl-2-(4-bromobenzoyl)-3-methyl-5-oxo-5,6-dihydrospiro[furo[3,2-g]chromene-7,4'-piperidine]-1'-carboxylate (5e). White solid; M.F: $\mathrm{C}_{28} \mathrm{H}_{28} \mathrm{BrNO}_{6}$; mp: $224-226{ }^{\circ} \mathrm{C}$; yield: $80 \%$; IR $\left(\mathrm{KBr}, \mathrm{cm}^{-1}\right): 2974,1683,1620,1246,1151 ;{ }^{1} \mathrm{H}$ NMR $(400 \mathrm{MHz}$, $\left.\mathrm{CDCl}_{3}\right) \delta 8.31(\mathrm{~s}, 1 \mathrm{H}), 7.95-7.93(\mathrm{~d}, J=8.7 \mathrm{~Hz}, 2 \mathrm{H}), 7.68-7.66(\mathrm{~d}, J$ $=8.7 \mathrm{~Hz}, 2 \mathrm{H}), 7.10(\mathrm{~s}, 1 \mathrm{H}), 3.88(\mathrm{bs}, 2 \mathrm{H}), 3.23(\mathrm{bs}, 2 \mathrm{H}), 2.80(\mathrm{~s}$, $2 \mathrm{H}), 2.62(\mathrm{~s}, 3 \mathrm{H}), 2.06-2.02(\mathrm{~m}, 2 \mathrm{H}), 1.70-1.66(\mathrm{~m}, 2 \mathrm{H}), 1.46(\mathrm{~s}$, $9 \mathrm{H}) ;{ }^{13} \mathrm{C} \mathrm{NMR}\left(100 \mathrm{MHz}, \mathrm{CDCl}_{3}\right) \delta$ 191.0, 183.9, 159.4, 158.8, 154.6, 148.9, 136.1, 131.6, 131.1, 128.2, 127.9, 124.3, 121.2, 118.7, 100.6, 79.9, 78.6, 48.0, 34.1, 28.3, 10.0; MS (ESI mass): $m /$ $z, 552[\mathrm{M}-\mathrm{H}]^{+}$.

4.3.2.6 2'-(4-Bromobenzoyl)-3'-methylspiro[cyclopentane-1, $7^{\prime}$ furo[3,2-g]chromen]-5' $\left(6^{\prime} H\right)$-one (5f). White solid; M.F: $\mathrm{C}_{23} \mathrm{H}_{19} \mathrm{BrO}_{4}$; mp: $130-132{ }^{\circ} \mathrm{C}$; yield: $77 \%$; IR $\left(\mathrm{KBr}, \mathrm{cm}^{-1}\right)$ : 2958, 1689, 1616, 1222, 1143; ${ }^{1} \mathrm{H}$ NMR (400 $\mathrm{MHz}, \mathrm{CDCl}_{3}$ ) $\delta 8.30(\mathrm{~s}, 1 \mathrm{H}), 7.95-7.92(\mathrm{~d}, J=8.7 \mathrm{~Hz}, 2 \mathrm{H}), 7.67-7.65(\mathrm{~d}, J=$ $8.7 \mathrm{~Hz}, 2 \mathrm{H}), 7.01(\mathrm{~s}, 1 \mathrm{H}), 2.90(\mathrm{~s}, 2 \mathrm{H}), 2.62(\mathrm{~s}, 3 \mathrm{H}), 2.13-2.08$ (m, 2H), 1.93-1.87 (m, 2H), 1.75-1.67 (m, 4H); ${ }^{13} \mathrm{C}$ NMR (100 $\left.\mathrm{MHz} \mathrm{CDCl}_{3}\right) \delta 192.1,183.9,160.9,158.7,148.7,136.3,131.6$, 131.1, 128.4, 127.8, 123.9, 121.3, 119.0, 100.6, 90.7, 47.1, 37.5, 23.8, 10.0; MS (ESI mass): $m / z, 437[\mathrm{M}-\mathrm{H}]^{+}$; HRMS: 438.0446.

4.3.2.7 2'-(4-Chlorobenzoyl)-3'-methylspiro[cyclohexane-1, $7^{\prime}$ furo[3,2-g]chromen]-5'(6'H)-one (5g). White solid; M.F: $\mathrm{C}_{24} \mathrm{H}_{21} \mathrm{ClO}_{4}$; mp: $126-128{ }^{\circ} \mathrm{C}$; yield: $79 \%$; IR $\left(\mathrm{KBr}, \mathrm{cm}^{-1}\right): 2929$, 1691, 1618, 1328, 1244, 1143; ${ }^{1} \mathrm{H}$ NMR (400 MHz, $\left.\mathrm{CDCl}_{3}\right) \delta 8.28$ (s, $1 \mathrm{H}), 8.03-8.01$ (d, $J=8.5 \mathrm{~Hz}, 2 \mathrm{H}), 7.50-7.48(\mathrm{~d}, J=8.5 \mathrm{~Hz}$, $2 \mathrm{H}), 7.07(\mathrm{~s}, 1 \mathrm{H}), 2.77(\mathrm{~s}, 2 \mathrm{H}), 2.62(\mathrm{~s}, 3 \mathrm{H}), 1.78-1.65(\mathrm{~m}, 3 \mathrm{H})$, 1.56-1.51 (m, 7H); ${ }^{13} \mathrm{C}$ NMR (100 MHz, $\left.\mathrm{CDCl}_{3}\right) \delta 192.1,183.7$, 160.2 , 158.9, 148.7, 139.1, 135.9, 131.0, 128.6, 123.9, 121.0, 119.0, 100.5, 80.7, 48.2, 34.9, 29.6, 25.0, 21.4, 10.0; MS (ESI mass): $m / z, 409[\mathrm{M}+\mathrm{H}]^{+}$.

4.3.2.8 tert-Butyl-2-(4-chlorobenzoyl)-3-methyl-5-oxo-5,6-dihydrospiro[furo[3,2-g]chromene-7,4'-piperidine]-1'-carboxylate (5h).
White solid; M.F: $\mathrm{C}_{28} \mathrm{H}_{28} \mathrm{ClNO}_{6}$; mp: $218-220{ }^{\circ} \mathrm{C}$; yield: $77 \%$; IR (KBr, $\mathrm{cm}^{-1}$ ): 2922, 1683, 1620, 1244, 1151; ${ }^{1} \mathrm{H}$ NMR $(400 \mathrm{MHz}$, $\left.\mathrm{CDCl}_{3}\right) \delta 8.31(\mathrm{~s}, 1 \mathrm{H}), 8.03-8.01(\mathrm{~d}, J=8.5 \mathrm{~Hz}, 2 \mathrm{H}), 7.51-7.49(\mathrm{~d}, J$ $=8.5 \mathrm{~Hz}, 2 \mathrm{H}), 7.10(\mathrm{~s}, 1 \mathrm{H}), 3.89(\mathrm{bs}, 2 \mathrm{H}), 3.23(\mathrm{bs}, 2 \mathrm{H}), 2.91(\mathrm{~s}$, $2 \mathrm{H}), 2.62(\mathrm{~s}, 3 \mathrm{H}), 2.12-2.03(\mathrm{~m}, 2 \mathrm{H}), 1.76-1.67(\mathrm{~m}, 2 \mathrm{H}), 1.46(\mathrm{~s}$, $9 \mathrm{H}) ;{ }^{13} \mathrm{C}$ NMR $\left(100 \mathrm{MHz}, \mathrm{CDCl}_{3}\right) \delta 191.0,183.7,159.4,158.8$, $154.6,148.9,139.2$, 135.7, 131.0, 130.1, 128.7, 124.3, 121.2, 118.7, 100.6, 99.6, 79.9, 78.5, 48.0, 47.5, 28.3, 10.0; MS (ESI mass): $m / z, 508[\mathbf{M}-\mathbf{H}]^{+}$.

4.3.2.9 2'-(4-Chlorobenzoyl)-3'-methylspiro[cyclopentane-1, $7^{\prime}$ furo[3,2-g]chromen]-5'(6'H)-one (5i). White solid; M.F: $\mathrm{C}_{23} \mathrm{H}_{19} \mathrm{ClO}_{4}$; mp: $125-127{ }^{\circ} \mathrm{C}$; yield: $80 \%$; IR $\left(\mathrm{KBr}, \mathrm{cm}^{-1}\right): 2954$, 1691, 1616, 1246, 1145; ${ }^{1} \mathrm{H}$ NMR (400 MHz, $\left.\mathrm{CDCl}_{3}\right) \delta 8.30(\mathrm{~s}, 1 \mathrm{H})$, 8.03-8.00 (d, $J=8.5 \mathrm{~Hz}, 2 \mathrm{H}), 7.51-7.48(\mathrm{~d}, J=8.5 \mathrm{~Hz}, 2 \mathrm{H}), 7.02$ (s, 1H), $2.90(\mathrm{~s}, 2 \mathrm{H}), 2.62(\mathrm{~s}, 3 \mathrm{H}), 2.13-2.08(\mathrm{~m}, 2 \mathrm{H}), 1.92-1.87$ $(\mathrm{m}, 2 \mathrm{H}), 1.75-1.66(\mathrm{~m}, 4 \mathrm{H}) ;{ }^{13} \mathrm{C} \mathrm{NMR}\left(100 \mathrm{MHz}, \mathrm{CDCl}_{3}\right) \delta 192.1$, $183.7,160.8,158.7,148.8,139.1,135.8,131.0,128.6,128.3$, 123.9, 121.2, 119.0, 100.6, 90.6, 47.1, 37.5, 23.8, 10.0; MS (ESI mass): $m / z, 393[\mathrm{M}-\mathrm{H}]^{+}$.

\subsection{General experimental procedure $7 \mathbf{a}-\mathbf{u}$}

4.4.1 Conventional method. A degassed mixture of $5 \mathbf{d}-\mathbf{f}$ (1.0 mmol), arylboronic acid $6 \mathbf{a}-\mathrm{g}(1.3 \mathrm{mmol}), \mathrm{Na}_{2} \mathrm{CO}_{3}(3.00$ $\mathrm{mmol}), \mathrm{Pd}\left(\mathrm{PPh}_{3}\right)_{4}(115 \mathrm{mg}, 0.10 \mathrm{mmol})$ and mixture of $1: 1: 1$ of toluene, ethanol, water $(9 \mathrm{~mL})$ was introduced into a round bottomed flask and heated it at $80{ }^{\circ} \mathrm{C}$ for $8 \mathrm{~h}$ with constant stirring under nitrogen atmosphere. The resulting solution was diluted with ice water and was extracted with ethyl acetate; the combined organic layers were washed with brine, dried over $\mathrm{Na}_{2} \mathrm{SO}_{4}$. The solvent was removed under reduced pressure, and the crude thus obtained was purified using column chromatography to afford titled compound $7(\mathbf{a}-\mathbf{u})$.

4.4.1.1 Sealed tube under conventional heating. A mixture of 5d-f (1.0 mmol), arylboronic acid $\mathbf{6 a}-\mathbf{g}$ (1.3 mmol), $\mathrm{Na}_{2} \mathrm{CO}_{3}(3.00$ $\mathrm{mmol})$, and mixture of $1: 1: 1$ of toluene, ethanol, water $(9 \mathrm{~mL})$ are degassed in a sealed pressure tube and $\mathrm{Pd}\left(\mathrm{PPh}_{3}\right)_{4}(115 \mathrm{mg}$, $0.10 \mathrm{mmol}$ ) was added followed by degassing and heated it at $80{ }^{\circ} \mathrm{C}$ for $6-7 \mathrm{~h}$ with constant stirring. The resulting solution was diluted with ice water and was extracted with ethyl acetate; the combined organic layers were washed with brine, dried over $\mathrm{Na}_{2} \mathrm{SO}_{4}$. The solvent was removed under reduced pressure, and the crude thus obtained was purified using column chromatography (using $5-10 \%$ petroleum ether/ethyl acetate) to afford titled compound $7 \mathbf{a}-\mathbf{u}$.

4.4.2 Microwave method. A mixture of $5 \mathrm{~d}-\mathrm{f}(1.0 \mathrm{mmol})$, arylboronic acid $\mathbf{6 a}-\mathbf{g}(1.3 \mathrm{mmol}), \mathrm{Na}_{2} \mathrm{CO}_{3}(3.00 \mathrm{mmol})$, and mixture of $1: 1: 1$ of toluene, ethanol, water $(9 \mathrm{~mL})$ are degassed in a sealed pressure tube and $\mathrm{Pd}\left(\mathrm{PPh}_{3}\right)_{4}(115 \mathrm{mg}, 0.10$ mmol) was added followed by degassing. This was introduced into CEM discover microwave reaction vessel equipped with a magnetic stirrer. The vessel was sealed and then placed into the microwave cavity. Initial microwave irradiation of $180 \mathrm{~W}$ was used, the temperature being ramped from room temperature to the desired $80{ }^{\circ} \mathrm{C}$ temperature. Once this was reached the reaction mixture was heated at this temperature for appropriate time. The resulting solution was diluted with ice water and was 
extracted with ethyl acetate; the combined organic layers were washed with brine, dried over $\mathrm{Na}_{2} \mathrm{SO}_{4}$. The solvent was removed under reduced pressure, and the crude thus obtained was purified column chromatography to afford titled compound 7au.

4.4.2.1 2'-([1,1'-Biphenyl]-4-carbonyl)-3'-methylspiro[cyclohexane-1,7'-furo[3,2-g]chromen]-5'(6'H)-one (7a). White solid; M.F: $\mathrm{C}_{30} \mathrm{H}_{26} \mathrm{O}_{4}$; mp: $172-174{ }^{\circ} \mathrm{C}$; yield: $83 \%$; IR $(\mathrm{KBr}$, $\left.\mathrm{cm}^{-1}\right): 2929,1687,1622,1290,1246,1151 ;{ }^{1} \mathrm{H}$ NMR $(400 \mathrm{MHz}$, $\left.\mathrm{CDCl}_{3}\right) \delta 8.29(\mathrm{~s}, 1 \mathrm{H}), 8.16-8.14(\mathrm{~d}, J=8.5 \mathrm{~Hz}, 2 \mathrm{H}), 7.76-7.74(\mathrm{~d}, J$ $=8.5 \mathrm{~Hz}, 2 \mathrm{H}), 7.68-7.66(\mathrm{~d}, J=7.2 \mathrm{~Hz}, 2 \mathrm{H}), 7.51-7.47(\mathrm{t}, J=$ $7.2 \mathrm{~Hz}, 2 \mathrm{H}), 7.44-7.40(\mathrm{t}, J=7.2 \mathrm{~Hz}, 1 \mathrm{H}), 7.01(\mathrm{~s}, 1 \mathrm{H}), 2.78(\mathrm{~s}$, $2 \mathrm{H}), 2.63(\mathrm{~s}, 3 \mathrm{H}), 2.04-2.00(\mathrm{~m}, 2 \mathrm{H}), 1.75-1.69(\mathrm{~m}, 4 \mathrm{H}), 1.56-1.51$ $(\mathrm{m}, 4 \mathrm{H}) ;{ }^{13} \mathrm{C}$ NMR $\left(100 \mathrm{MHz}, \mathrm{CDCl}_{3}\right) \delta 192.2,184.7,160.0,158.9$, $149.1,145.4,140.0,136.3,130.23$, 128.9, 128.2, 127.8, 127.3, 127.0, 124.0, 118.9, 100.5, 80.7, 48.3, 34.9, 25.1, 21.4, 10.1; MS (ESI mass): $m / z, 451[\mathrm{M}+\mathrm{H}]^{+}$.

4.4.2.2 4'-(3'-Methyl-5'-oxo-5', $6^{\prime}$-dihydrospiro[cyclohexane- $1,7^{\prime}$ furo[3,2-g]chromen]-2'-ylcarbonyl)-[1,1'-biphenyl]-4-carbaldehyde (7b). White solid; M.F: $\mathrm{C}_{31} \mathrm{H}_{26} \mathrm{O}_{5}$; mp: $168-170{ }^{\circ} \mathrm{C}$; yield: $82 \%$; IR $\left(\mathrm{KBr}, \mathrm{cm}^{-1}\right): 2929,1687,1625,1292,1220,1145 ;{ }^{1} \mathrm{H}$ NMR $(400$ $\left.\mathrm{MHz} \mathrm{CDCl}_{3}\right) \delta 10.09(\mathrm{~s}, 1 \mathrm{H}), 8.30(\mathrm{~s}, 1 \mathrm{H}), 8.19-8.17(\mathrm{~d}, J=$ $8.5 \mathrm{~Hz}, 2 \mathrm{H}), 8.02-8.00(\mathrm{~d}, J=8.5 \mathrm{~Hz}, 2 \mathrm{H}), 7.85-7.83(\mathrm{~d}, J=$ $8.2 \mathrm{~Hz}, 2 \mathrm{H}), 7.80-7.78(\mathrm{~d}, J=8.2 \mathrm{~Hz}, 2 \mathrm{H}), 7.10(\mathrm{~s}, 1 \mathrm{H}), 2.78(\mathrm{~s}$, $2 \mathrm{H}), 2.65(\mathrm{~s}, 3 \mathrm{H}), 2.04-2.00(\mathrm{~m}, 2 \mathrm{H}), 1.78-1.69(\mathrm{~m}, 4 \mathrm{H}), 1.57-1.51$ $(\mathrm{m}, 4 \mathrm{H}) ;{ }^{13} \mathrm{C}$ NMR $\left(100 \mathrm{MHz}, \mathrm{CDCl}_{3}\right) \delta 192.2,191.7,184.4,160.1$, $158.9,148.9,145.8,143.7,137.3,135.7,130.3$, 128.2, 127.9, 127.3, 123.9, 121.0, 118.9, 100.5, 80.7, 48.2 , 34.8, 29.6, 25.0, 21.4, 10.0; MS (ESI mass): $m / z, 479[\mathrm{M}+\mathrm{H}]^{+}$.

4.4.2.3 2'-(4'-Chloro-[1,1'-biphenyl]-4-carbonyl)-3'-methylspiro [cyclohexane-1, $7^{\prime}$-furo[3,2-g]chromen]-5' $\left(6^{\prime} H\right)$-one (7c). White solid; M.F: $\mathrm{C}_{30} \mathrm{H}_{25} \mathrm{ClO}_{4}$; mp: $186-188{ }^{\circ} \mathrm{C}$; yield: $84 \%$; IR $(\mathrm{KBr}$, $\mathrm{cm}^{-1}$ ): 2924, 1689, 1616, 1296, 1143; ${ }^{1} \mathrm{H}$ NMR (400 MHz, $\mathrm{CDCl}_{3}$ ) $\delta 8.29(\mathrm{~s}, 1 \mathrm{H}), 8.15-8.13(\mathrm{~d}, J=8.5 \mathrm{~Hz}, 2 \mathrm{H}), 7.72-7.70(\mathrm{~d}, J=$ $8.7 \mathrm{~Hz}, 2 \mathrm{H}), 7.61-7.59(\mathrm{~d}, J=8.5 \mathrm{~Hz}, 2 \mathrm{H}), 7.47-7.45(\mathrm{~d}, J=8.7 \mathrm{~Hz}$, 2H), $7.09(\mathrm{~s}, 1 \mathrm{H}), 2.78(\mathrm{~s}, 2 \mathrm{H}), 2.63(\mathrm{~s}, 3 \mathrm{H}), 2.04-2.00(\mathrm{~m}, 2 \mathrm{H})$, 1.78-1.68 (m, 4H), 1.56-1.51 (m, 4H); $\left.{ }^{13} \mathrm{C} \mathrm{NMR} \mathrm{(100} \mathrm{MHz,} \mathrm{CDCl}_{3}\right)$ $\delta$ 192.2, 184.5, 160.1, 158.9, 149.0, 144.0, 138.4, 136.6, 134.4, 130.3, 129.1, 128.5, 127.9, 126.8, 124.0, 120.9, 118.9, 100.5, 80.7, 48.2, 34.8, 25.0, 21.4, 10.0; MS (ESI mass): $m / z, 485[\mathrm{M}+\mathrm{H}]^{+}$.

4.4.2.4 3'-Methyl-2'-(4'-methyl-[1,1'-biphenyl]-4-carbonyl)spiro [cyclohexane-1, $7^{\prime}$-furo[3,2-g]chromen]- $5^{\prime}\left(6^{\prime} H\right)$-one (7d). White solid; M.F: $\mathrm{C}_{30} \mathrm{H}_{25} \mathrm{ClO}_{4}$; mp: $190-192{ }^{\circ} \mathrm{C}$; yield: $87 \%$; IR $(\mathrm{KBr}$, $\mathrm{cm}^{-1}$ ): 2931, 1689, 1616, 1294, 1143; ${ }^{1} \mathrm{H}$ NMR (400 MHz, $\mathrm{CDCl}_{3}$ ) $\delta 8.28(\mathrm{~s}, 1 \mathrm{H}), 8.14-8.12(\mathrm{~d}, J=8.5 \mathrm{~Hz}, 2 \mathrm{H}), 7.74-7.72(\mathrm{~d}, J=$ $8.5 \mathrm{~Hz}, 2 \mathrm{H}), 7.59-7.57(\mathrm{~d}, J=8.0 \mathrm{~Hz}, 2 \mathrm{H}), 7.31-7.29(\mathrm{~d}, J=$ $8.0 \mathrm{~Hz}, 2 \mathrm{H}), 7.10(\mathrm{~s}, 1 \mathrm{H}), 2.78(\mathrm{~s}, 2 \mathrm{H}), 2.62(\mathrm{~s}, 3 \mathrm{H}), 2.42(\mathrm{~s}, 3 \mathrm{H})$, 2.04-2.00 (m, 2H), 1.78-1.65 (m, 4H), 1.56-1.51 (m, 4H); ${ }^{13} \mathrm{C}$ NMR (100 MHz, $\left.\mathrm{CDCl}_{3}\right) \delta$ 192.2, 184.7, 160.0, 158.9, 149.1, 145.3, $138.1,137.0$, 136.0, 130.2, 129.6, 127.6, 127.1, 126.7, 124.0, $120.8,118.8,100.5,80.6,48.2,34.8,25.0,21.4,21.1,10.0 ; \mathrm{MS}$ (ESI mass): $m / z, 465[\mathrm{M}+\mathrm{H}]^{+}$; HRMS: 464.19812 .

4.4.2.5 3'-Methyl-2'-(4-(naphthalen-1-yl)benzoyl)spiro[cyclohexane-1, $7^{\prime}$-furo[3,2-g]chromen]-5'(6'H)-one (7e). White solid; M.F: $\mathrm{C}_{34} \mathrm{H}_{28} \mathrm{O}_{4}$; mp: $152-154{ }^{\circ} \mathrm{C}$; yield: $86 \%$; IR $(\mathrm{KBr}$, $\left.\mathrm{cm}^{-1}\right): 2929,1689,1622,1292,1145 ;{ }^{1} \mathrm{H}$ NMR (400 MHz, $\mathrm{CDCl}_{3}$ ) $\delta 8.31(\mathrm{~s}, 1 \mathrm{H}), 8.21-8.19(\mathrm{~d}, J=8.5 \mathrm{~Hz}, 2 \mathrm{H}), 7.95-7.90(\mathrm{~m}, 3 \mathrm{H})$,
7.68-7.65 (d, J=8.5 Hz, 2H), 7.59-7.46 (m, 4H), $7.13(\mathrm{~s}, 1 \mathrm{H}), 2.78$ (s, 2H), 2.67 (s, 3H), 2.04-2.01 (m, 2H), 1.75-1.65 (m, 4H), 1.54$1.47(\mathrm{~m}, 4 \mathrm{H}) ;{ }^{13} \mathrm{C} \mathrm{NMR}\left(100 \mathrm{MHz}, \mathrm{CDCl}_{3}\right) \delta$ 192.2, 184.8, 160.0, 158.9, 149.1, 145.4, 139.1, 136.4, 133.7, 131.2, 130.0, 129.7, 128.3, 127.9, 125.9, 125.6, 125.3, 124.0, 120.9, 118.9, 100.5, 80.6, 48.3, 34.8, 25.0, 21.4, 10.0; MS (ESI mass): $m / z, 501[\mathrm{M}+\mathrm{H}]^{+}$.

4.4.2.6 2'-(3',5'-Dichloro-[1,1'-biphenyl]-4-carbonyl)-3'-methylspiro[cyclohexane-1,7'-furo[3,2-g]chromen]-5' $\left(6^{\prime} H\right)$-one (7f). White solid; M.F: $\mathrm{C}_{30} \mathrm{H}_{24} \mathrm{Cl}_{2} \mathrm{O}_{4}$; mp: $178-180{ }^{\circ} \mathrm{C}$; yield: $85 \%$; IR ( $\mathrm{KBr}$, $\mathrm{cm}^{-1}$ ): 2929, 1687, 1627, 1292, 1147; ${ }^{1} \mathrm{H}$ NMR (400 MHz, $\mathrm{CDCl}_{3}$ ) $\delta 8.29(\mathrm{~s}, 1 \mathrm{H}), 8.16-8.14(\mathrm{~d}, J=8.5 \mathrm{~Hz}, 2 \mathrm{H}), 7.70-7.68(\mathrm{~d}, J=$ $8.5 \mathrm{~Hz}, 2 \mathrm{H}), 7.54-7.53(\mathrm{~d}, J=1.7 \mathrm{~Hz}, 2 \mathrm{H}), 7.40(\mathrm{t}, J=1.7 \mathrm{~Hz}, 1 \mathrm{H})$, 7.09 (s, 1H), 2.78 (s, 2H), $2.64(\mathrm{~s}, 3 \mathrm{H}), 2.04-2.00(\mathrm{~m}, 2 \mathrm{H}), 1.75-$ $1.66(\mathrm{~m}, 4 \mathrm{H}), 1.54-1.51(\mathrm{~m}, 4 \mathrm{H}) ;{ }^{13} \mathrm{C}$ NMR (100 MHz, $\mathrm{CDCl}_{3}$ ) $\delta$ 192.1, 184.3, 160.1, 158.9, 148.9, 142.4, 137.3, 135.5, 130.3, 128.2, 125.7, 123.9, 121.0, 118.9, 100.5, 80.7, 48.2, 34.8, 29.6, 25.0, 21.4, 10.0; MS (ESI mass): $m / z, 519[\mathrm{M}+\mathrm{H}]^{+}$.

4.4.2.7 2'-(4'-Fluoro-[1,1'-biphenyl]-4-carbonyl)-3'-methylspiro [cyclohexane-1, $7^{\prime}$-furo[3,2-g]chromen]-5' $\left(6^{\prime} H\right)$-one (7g). White solid; M.F: $\mathrm{C}_{30} \mathrm{H}_{25} \mathrm{FO}_{4}$; mp: $160-162{ }^{\circ} \mathrm{C}$; yield: $84 \%$; IR $(\mathrm{KBr}$, $\left.\mathrm{cm}^{-1}\right): 2931,1685,1614,1336,1246,1149 ;{ }^{1} \mathrm{H}$ NMR $(400 \mathrm{MHz}$, $\left.\mathrm{CDCl}_{3}\right) \delta 8.29(\mathrm{~s}, 1 \mathrm{H}), 8.15-8.13(\mathrm{~d}, J=8.5 \mathrm{~Hz}, 2 \mathrm{H}), 7.71-7.68(\mathrm{~d}, J$ $=8.5 \mathrm{~Hz}, 2 \mathrm{H}), 7.65-7.62(\mathrm{~m}, 2 \mathrm{H}), 7.20-7.16(\mathrm{t}, J=8.7 \mathrm{~Hz}, 2 \mathrm{H})$, $7.09(\mathrm{~s}, 1 \mathrm{H}), 2.78(\mathrm{~s}, 2 \mathrm{H}), 2.63(\mathrm{~s}, 3 \mathrm{H}), 2.04-2.00(\mathrm{~m}, 2 \mathrm{H}), 1.75-$ $1.68(\mathrm{~m}, 4 \mathrm{H}), 1.55-1.51(\mathrm{~m}, 2 \mathrm{H}), 1.27-1.24(\mathrm{~m}, 2 \mathrm{H}) ;{ }^{13} \mathrm{C} \mathrm{NMR}$ $\left(100 \mathrm{MHz}, \mathrm{CDCl}_{3}\right) \delta 192.2,184.6,164.2,161.7,160.0,158.9$, $149.0,144.3,136.3,130.3,128.9,127.8,126.8,124.0,120.9$, 118.8, 115.7, 100.5, 80.7, 48.2, 34.8, 25.0, 21.4, 10.0; MS (ESI mass): $m / z, 469[\mathrm{M}+\mathrm{H}]^{+}$.

4.4.2.8 tert-Butyl-2-([1,1'-biphenyl]-4-carbonyl)-3-methyl-5-oxo5,6-dihydrospiro[furo[3,2-g]chromene-7,4'-piperidine]-1'-carboxylate (7h). White solid; M.F: $\mathrm{C}_{34} \mathrm{H}_{33} \mathrm{NO}_{6}$; mp: $204-207{ }^{\circ} \mathrm{C}$; yield: $82 \%$; IR (KBr, cm $\left.{ }^{-1}\right): 2992,1683,1618,1246,1151 ;{ }^{1} \mathrm{H}$ NMR $(400 \mathrm{MHz}$, $\left.\mathrm{CDCl}_{3}\right) \delta 8.31(\mathrm{~s}, 1 \mathrm{H}), 8.15-8.13(\mathrm{~d}, J=8.5 \mathrm{~Hz}, 2 \mathrm{H}), 7.76-7.74(\mathrm{~d}, J$ $=8.5 \mathrm{~Hz}, 2 \mathrm{H}), 7.69-7.67(\mathrm{~d}, J=7.2 \mathrm{~Hz}, 2 \mathrm{H}), 7.52-7.48(\mathrm{t}, J=$ $7.2 \mathrm{~Hz}, 2 \mathrm{H}), 7.44-7.40(\mathrm{t}, J=7.2 \mathrm{~Hz}, 1 \mathrm{H}), 7.12(\mathrm{~s}, 1 \mathrm{H}), 3.90$ (bs, $2 \mathrm{H}), 3.23(\mathrm{bs}, 2 \mathrm{H}), 2.80(\mathrm{~s}, 2 \mathrm{H}), 2.64(\mathrm{~s}, 3 \mathrm{H}), 2.07-2.03(\mathrm{~m}, 2 \mathrm{H})$, 1.70-1.63 (m, 2H), $1.46(\mathrm{~s}, 9 \mathrm{H}) ;{ }^{13} \mathrm{C} \mathrm{NMR} \mathrm{(100} \mathrm{MHz,} \mathrm{CDCl}_{3}$ ) $\delta 191.2,184.7,159.3,154.7,149.3,145.4,139.9,138.2,130.3$, $129.7,128.9,128.2$, 127.3, 127.0, 126.7, 121.2, 120.9, 118.7, 100.6, 79.9, 78.5, 48.3 , 34.9, 28.4, 21.4, 10.0; MS (ESI mass): $m / z$, $552[\mathrm{M}+\mathrm{H}]^{+}$; HRMS: 551.23011 .

4.4.2.9 tert-Butyl-2-(4'-formyl-[1,1'-biphenyl]-4-carbonyl)-3methyl-5-oxo-5, 6-dihydrospiro[furo[3,2-g]chromene-7,4'-piperidine]$1^{\prime}$-carboxylate (7i). White solid; M.F: $\mathrm{C}_{35} \mathrm{H}_{33} \mathrm{NO}_{7}$; mp: 210$212{ }^{\circ} \mathrm{C}$; yield: 80\%; IR (KBr, $\left.\mathrm{cm}^{-1}\right)$ : 2924, 1689, 1627, 1419, 1153; ${ }^{1} \mathrm{H}$ NMR $\left(400 \mathrm{MHz}, \mathrm{CDCl}_{3}\right) \delta 10.09(\mathrm{~s}, 1 \mathrm{H}), 8.32$ (s, 1H), 8.19-8.17 $(\mathrm{d}, J=8.2 \mathrm{~Hz}, 2 \mathrm{H}), 8.02-8.00(\mathrm{~d}, J=8.2 \mathrm{~Hz}, 2 \mathrm{H}), 7.85-7.79(\mathrm{~m}$, $4 \mathrm{H}), 7.12$ (s, 1H), 3.91 (bs, 2H), 3.24 (bs, 2H), 2.80 (s, 2H), 2.65 (s, $3 \mathrm{H})$, 2.07-2.03 (m, 2H), 1.69-1.64 (m, 2H), 1.46 (s, 9H); ${ }^{13} \mathrm{C}$ NMR $\left(100 \mathrm{MHz}, \mathrm{CDCl}_{3}\right) \delta 191.8,191.1,184.5,159.4,154.7,149.2$, $145.8,143.8,137.2,135.8,130.4$, 127.9, 127.3, 124.4, 121.3, 118.8, 100.6, 79.9, 78.6, 48.1, 29.7, 28.4, 22.7, 21.4, 14.1, 10.1; MS (ESI mass): $m / z, 580[\mathrm{M}+\mathrm{H}]^{+}$.

4.4.2.10 tert-Butyl-2-(4'-chloro-[1,1'-biphenyl]-4-carbonyl)-3methyl-5-oxo-5, 6-dihydrospiro[furo[3,2-g]chromene-7,4'-piperidine]$1^{\prime}$-carboxylate (7j). White solid; M.F: $\mathrm{C}_{34} \mathrm{H}_{32} \mathrm{ClNO}_{6} ; \mathrm{mp}: 218-$ 
$220{ }^{\circ} \mathrm{C}$; yield: $83 \%$; IR $\left(\mathrm{KBr}, \mathrm{cm}^{-1}\right): 2924,1683,1618,1246,1151$; ${ }^{1} \mathrm{H}$ NMR (400 MHz, $\left.\mathrm{CDCl}_{3}\right) \delta 8.32(\mathrm{~s}, 1 \mathrm{H}), 8.15-8.13(\mathrm{~d}, J=$ $8.5 \mathrm{~Hz}, 2 \mathrm{H}), 7.72-7.70(\mathrm{~d}, J=8.5 \mathrm{~Hz}, 2 \mathrm{H}), 7.1-7.59(\mathrm{~d}, J=8.7 \mathrm{~Hz}$, $2 \mathrm{H}), 7.47-7.45$ (d, $J=8.7 \mathrm{~Hz}, 2 \mathrm{H}), 7.12(\mathrm{~s}, 1 \mathrm{H}), 3.89$ (bs, 2H), 3.25 (bs, 2H), 2.80 (s, 2H), 2.64 (s, 3H), 2.07-2.01 (m, 2H), 1.66-1.70 $(\mathrm{m}, 2 \mathrm{H}), 1.46(\mathrm{~s}, 9 \mathrm{H}) ;{ }^{13} \mathrm{C} \mathrm{NMR}\left(100 \mathrm{MHz}, \mathrm{CDCl}_{3}\right) \delta$ 191.1, 184.6, $159.4,158.9,154.7,149.3,144.2$, 138.4, 136.5, 134.4, 130.3, 129.2, 128.5, 126.9, 124.5, 121.2, 118.7, 100.6, 79.9, 78.6, 48.1, 34.1, 29.7, 28.4, 14.1, 10.0; MS (ESI mass): $m / z, 586[\mathrm{M}+\mathrm{H}]^{+}$.

4.4.2.11 tert-Butyl-3-methyl-2-(4'-methyl-[1,1'-biphenyl]-4carbonyl)-5-oxo-5,6-dihydrospiro[furo[3,2-g]chromene-7, $4^{\prime}$-piperidine]-1'-carboxylate (7k). White solid; M.F: $\mathrm{C}_{35} \mathrm{H}_{35} \mathrm{NO}_{6} ; \mathrm{mp}$ : 224-227 ${ }^{\circ} \mathrm{C}$; yield: 85\%; IR (KBr, $\left.\mathrm{cm}^{-1}\right)$ : 2974, 1683, 1620, 1246, $1151 ;{ }^{1} \mathrm{H}$ NMR $\left(400 \mathrm{MHz}, \mathrm{CDCl}_{3}\right) \delta 8.31(\mathrm{~s}, 1 \mathrm{H}), 8.14-8.12(\mathrm{~d}, J=$ $8.2 \mathrm{~Hz}, 2 \mathrm{H}), 7.74-7.72(\mathrm{~d}, J=8.2 \mathrm{~Hz}, 2 \mathrm{H}), 7.59-7.57(\mathrm{~d}, J=$ $8.0 \mathrm{~Hz}, 2 \mathrm{H}), 7.31-7.29$ (d, $J=8.0 \mathrm{~Hz}, 2 \mathrm{H}), 7.12$ (s, 1H), 3.90 (bs, $2 \mathrm{H}), 3.24$ (bs, 2H), 2.80 (s, 2H), $2.63(\mathrm{~s}, 3 \mathrm{H}), 2.42$ (s, 3H), 2.07$2.03(\mathrm{~m}, 2 \mathrm{H}), 1.70-1.65(\mathrm{~m}, 2 \mathrm{H}), 1.48(\mathrm{~s}, 9 \mathrm{H}) ;{ }^{13} \mathrm{C}$ NMR $(100 \mathrm{MHz}$, $\left.\mathrm{CDCl}_{3}\right) \delta 191.1,184.7,159.3,158.9,154.7,149.4,145.5,138.2$, $137.0,135.9,130.3,129.7,127.4,127.1,126.8,124.5,121.1$, 118.6, 100.6, 79.9, 78.5, 48.1, 34.1, 29.7, 28.4, 21.2, 10.0; MS (ESI mass): $m / z, 566[\mathrm{M}+\mathrm{H}]^{+}$.

4.4.2.12 tert-Butyl-3-methyl-2-(4-(naphthalen-1-yl)benzoyl)-5oxo-5, 6-dihydrospiro[furo[3,2-g]chromene-7,4'-piperidine]-1'-carboxylate (7l). White solid; M.F: $\mathrm{C}_{38} \mathrm{H}_{35} \mathrm{NO}_{6}$; mp: $147-148{ }^{\circ} \mathrm{C}$; yield: $84 \%$; IR (KBr, $\mathrm{cm}^{-1}$ ): 2972, 1673, 1624, 1243, 1192; ${ }^{1} \mathrm{H}$ NMR (400 MHz, $\left.\mathrm{CDCl}_{3}\right) \delta 8.33(\mathrm{~s}, 1 \mathrm{H}), 8.21-8.18(\mathrm{~d}, J=8.2 \mathrm{~Hz}$, $2 \mathrm{H}), 7.95-7.91(\mathrm{t}, J=8.0 \mathrm{~Hz}, 3 \mathrm{H}), 7.68-7.66(\mathrm{~d}, J=8.2 \mathrm{~Hz}, 2 \mathrm{H})$, 7.59-7.46 (m, 4H), 7.16 (s, 1H), 3.90 (bs, 2H), 3.24 (bs, 2H), 2.80 (s, 2H), 2.67 (s, 3H), 2.07-2.04 (m, 2H), 1.70-1.64 (m, 2H), 1.46 $(\mathrm{s}, 9 \mathrm{H}) ;{ }^{13} \mathrm{C} \mathrm{NMR}\left(100 \mathrm{MHz}, \mathrm{CDCl}_{3}\right) \delta 191.1,184.9,159.3,158.9$, $154.7,149.3$, 145.5, 139.1, 136.4, 133.8, 131.2, 130.1, 129.7, $128.3,127.7,126.9,126.4,126.0,125.6,125.3$, 124.5, 121.2, 118.7, 100.7, 79.9, 78.6, 48.1, 34.1, 29.7, 28.4, 22.6, 10.0; MS (ESI mass): $m / z, 602[\mathrm{M}+\mathrm{H}]^{+}$.

4.4.2.13 tert-Butyl-2-( $3^{\prime}, 5^{\prime}$-dichloro-[1,1'-biphenyl]-4-carbonyl)3-methyl-5-oxo-5,6-dihydro spiro[furo[3,2-g]chromene-7,4'-piperidine]-1'-carboxylate (7m). White solid; M.F: $\mathrm{C}_{34} \mathrm{H}_{31} \mathrm{Cl}_{2} \mathrm{NO}_{6}$; mp: 207-208 ${ }^{\circ} \mathrm{C}$; yield: 86\%; IR (KBr, $\mathrm{cm}^{-1}$ ): 2924, 1691, 1616, 1244, $1151 ;{ }^{1} \mathrm{H}$ NMR $\left(400 \mathrm{MHz}, \mathrm{CDCl}_{3}\right) \delta 8.32(\mathrm{~s}, 1 \mathrm{H}), 8.16-8.14(\mathrm{~d}, J=$ $8.5 \mathrm{~Hz}, 2 \mathrm{H}), 7.70-7.68(\mathrm{~d}, J=8.5 \mathrm{~Hz}, 2 \mathrm{H}), 7.54-7.53(\mathrm{~d}, J=1.7 \mathrm{~Hz}$, 2H), 7.40-7.15 (d, $J=1.7 \mathrm{~Hz}, 1 \mathrm{H}), 7.12(\mathrm{~s}, 1 \mathrm{H}), 3.89(\mathrm{bs}, 2 \mathrm{H}), 3.25$ (bs, 2H), 2.80 (s, 2H), 2.64 (s, 3H), 2.07-2.03 (m, 2H), 1.70-1.64 $(\mathrm{m}, 2 \mathrm{H}), 1.46$ (s, 9H); ${ }^{13} \mathrm{C} \mathrm{NMR}\left(100 \mathrm{MHz}, \mathrm{CDCl}_{3}\right) \delta 191.1,184.4$, 159.4, 158.9, 154.7, 149.1, 142.9, 142.6, 137.3, 135.5, 130.4, 128.0, 127.0, 125.8, 124.4, 121.3, 118.8, 100.6, 79.9, 78.6, 48.1, 34.2, 29.7, 28.4, 10.0; MS (ESI mass): $m / z, 620[\mathrm{M}+\mathrm{H}]^{+}$.

4.4.2.14 tert-Butyl-2-(4'-fluoro-[1,1'-biphenyl]-4-carbonyl)-3methyl-5-oxo-5, 6-dihydrospiro[furo[3,2-g]chromene-7,4'-piperidine]$1^{\prime}$-carboxylate (7n). White solid; M.F: $\mathrm{C}_{34} \mathrm{H}_{32} \mathrm{FNO}_{6} ; \mathrm{mp}: 208-$ $210{ }^{\circ} \mathrm{C}$; yield: $87 \%$; IR $\left(\mathrm{KBr}, \mathrm{cm}^{-1}\right)$ : 2922, 1681, 1622, 1244, 1153; ${ }^{1} \mathrm{H} \mathrm{NMR}\left(400 \mathrm{MHz}, \mathrm{CDCl}_{3}\right) \delta 8.31(\mathrm{~s}, 1 \mathrm{H}), 8.15-8.13(\mathrm{~d}, J=8.5 \mathrm{~Hz}$, $2 \mathrm{H}), 7.71-7.69(\mathrm{~d}, J=8.5 \mathrm{~Hz}, 2 \mathrm{H}), 7.65-7.62(\mathrm{~m}, 2 \mathrm{H}), 7.20-7.16(\mathrm{t}$, $J=8.7 \mathrm{~Hz}, 2 \mathrm{H}), 7.12$ (s, 1H), 3.90 (bs, 2H), 3.24 (bs, 2H), 2.80 (s, $2 \mathrm{H}), 2.64(\mathrm{~s}, 3 \mathrm{H}), 2.07-2.03(\mathrm{~m}, 2 \mathrm{H}), 1.70-1.66(\mathrm{~m}, 2 \mathrm{H}), 1.46(\mathrm{~s}$, 9H); $\left.{ }^{13} \mathrm{C} \mathrm{NMR} \mathrm{(100} \mathrm{MHz,} \mathrm{CDCl}_{3}\right) \delta$ 191.1, 184.6, 159.3, 158.8, 154.7, 149.3, 144.5, 136.2, 132.1, 132.0, 130.3, 129.0, 128.9, 128.4,
126.8, 124.5, 121.2, 118.6, 116.0, 115.8, 100.6, 79.9, 78.6, 48.1, 28.4, 10.0; MS (ESI mass): $m / z, 570[\mathrm{M}+\mathrm{H}]^{+}$.

4.4.2.15 2'-([1,1'-Biphenyl]-4-carbonyl)-3'-methylspiro[cyclopentane-1,7'-furo[3,2-g]chromen]-5'(6'H)-one (7o). White solid; M.F: $\mathrm{C}_{29} \mathrm{H}_{24} \mathrm{O}_{4}$; mp: $118-120{ }^{\circ} \mathrm{C}$; yield: $86 \%$; IR $(\mathrm{KBr}$, $\mathrm{cm}^{-1}$ ): 2962, 1689, 1616, 1234, 1151; ${ }^{1} \mathrm{H}$ NMR (400 MHz, $\mathrm{CDCl}_{3}$ ) $\delta 8.30(\mathrm{~s}, 1 \mathrm{H}), 8.15-8.13(\mathrm{~d}, J=8.5 \mathrm{~Hz}, 2 \mathrm{H}), 7.76-7.74(\mathrm{~d}, J=$ $8.5 \mathrm{~Hz}, 2 \mathrm{H}), 7.69-7.67(\mathrm{~d}, J=7.7 \mathrm{~Hz}, 2 \mathrm{H}), 7.51-7.47(\mathrm{t}, J=7.7 \mathrm{~Hz}$, 2H), 7.44-7.39 (m, 1H), $7.05(\mathrm{~s}, 1 \mathrm{H}), 2.91(\mathrm{~s}, 2 \mathrm{H}), 2.63(\mathrm{~s}, 3 \mathrm{H})$, 2.14-2.09 (m, 2H), 1.92-1.88 (m, 2H), 1.75-1.68 (m, 4H); ${ }^{13} \mathrm{C}$ NMR (100 MHz, $\left.\mathrm{CDCl}_{3}\right) \delta 192.2,184.8,160.8,158.8,149.2,145.5$, 139.9, 136.3, 130.2, 128.9, 128.2, 127.7, 127.3, 127.0, 124.1, 121.2, 118.9, 100.7, 90.6, 47.1, 37.5, 23.8, 10.0; MS (ESI mass): $\mathrm{m} /$ $z, 437[\mathrm{M}+\mathrm{H}]^{+}$.

4.4.2.16 $4^{\prime}-\left(3^{\prime}-\right.$ Methyl-5'-oxo- $5^{\prime}, 6^{\prime}$-dihydrospiro[cyclopentane1,7'-furo[3,2-g]chromen]-2'-ylcarbonyl)-[1,1'-biphenyl]-4-carbaldehyde (7p). White solid; M.F: $\mathrm{C}_{30} \mathrm{H}_{24} \mathrm{O}_{5}$; mp: $182-184{ }^{\circ} \mathrm{C}$; yield: $88 \%$; IR $\left(\mathrm{KBr}, \mathrm{cm}^{-1}\right): 2958,1693,1622,1290,1213,1143 ;{ }^{1} \mathrm{H}$ NMR (400 $\left.\mathrm{MHz}, \mathrm{CDCl}_{3}\right) \delta 10.09(\mathrm{~s}, 1 \mathrm{H}), 8.32(\mathrm{~s}, 1 \mathrm{H}), 8.19-8.16(\mathrm{~d}, J=$ $8.5 \mathrm{~Hz}, 2 \mathrm{H}), 8.02-8.00(\mathrm{~d}, J=8.5 \mathrm{~Hz}, 2 \mathrm{H}), 7.85-7.83(\mathrm{~d}, J=$ $8.2 \mathrm{~Hz}, 2 \mathrm{H}), 7.80-7.78$ (d, $J=8.2 \mathrm{~Hz}, 2 \mathrm{H}), 7.04(\mathrm{~s}, 1 \mathrm{H}), 2.91$ (s, 2H), 2.65 (s, 3H), 2.14-2.09 (m, 2H), 1.93-1.88 (m, 2H), 1.77-1.68 $(\mathrm{m}, 4 \mathrm{H}) ;{ }^{13} \mathrm{C}$ NMR $\left(100 \mathrm{MHz}, \mathrm{CDCl}_{3}\right) \delta 192.1,191.7,184.5,160.8$, $158.8,149.0,145.8,143.7,137.3,135.7,130.3,128.2$, 127.9, 127.3, 124.0, 121.2, 119.0, 100.6, 90.6, 47.1, 37.5, 23.8, 10.0; MS (ESI mass): $m / z, 465[\mathrm{M}+\mathrm{H}]^{+}$.

4.4.2.17 2'-(4'-Chloro-[1,1'-biphenyl]-4-carbonyl)-3'-methylspiro[cyclopentane-1,7'-furo[3,2-g]chromen]-5' $\left(6^{\prime} H\right)$-one

$(7 \boldsymbol{q})$. White solid; M.F: $\mathrm{C}_{29} \mathrm{H}_{23} \mathrm{ClO}_{4}$; mp: $138-140{ }^{\circ} \mathrm{C}$; yield: $83 \%$; IR $\left(\mathrm{KBr}, \mathrm{cm}^{-1}\right)$ : 2924, 1687, 1612, 1236, 1149; ${ }^{1} \mathrm{H}$ NMR $(400 \mathrm{MHz}$, $\left.\mathrm{CDCl}_{3}\right) \delta 8.31(\mathrm{~s}, 1 \mathrm{H}), 8.15-8.13(\mathrm{~d}, J=8.5 \mathrm{~Hz}, 2 \mathrm{H}), 7.72-7.70(\mathrm{~d}, J$ $=8.5 \mathrm{~Hz}, 2 \mathrm{H}), 7.61-7.59(\mathrm{~d}, J=8.7 \mathrm{~Hz}, 2 \mathrm{H}), 7.47-7.45(\mathrm{~d}, J=$ $8.7 \mathrm{~Hz}, 2 \mathrm{H}), 7.04(\mathrm{~s}, 1 \mathrm{H}), 2.91(\mathrm{~s}, 2 \mathrm{H}), 2.63(\mathrm{~s}, 3 \mathrm{H}), 2.13-2.08(\mathrm{~m}$, $2 \mathrm{H}), 1.92-1.88(\mathrm{~m}, 2 \mathrm{H}), 1.76-1.68(\mathrm{~m}, 4 \mathrm{H}) ;{ }^{13} \mathrm{C}$ NMR $(100 \mathrm{MHz}$, $\left.\mathrm{CDCl}_{3}\right) \delta 192.2,184.6,160.8,158.8,149.1,144.0,138.4,136.6$, 134.4, 130.3, 129.1, 128.5, 127.9, 126.8, 124.0, 121.2, 119.0, 90.6, 47.1, 37.5, 23.8, 10.0; MS (ESI mass): $m / z, 471[\mathrm{M}+\mathrm{H}]^{+}$; HRMS: 470.12822 .

4.4.2.18 3'-Methyl-2'-(4'-methyl-[1,1'-biphenyl]-4-carbonyl) spiro[cyclopentane-1, $7^{\prime}$-furo[3,2-g]chromen]-5' $\left(6^{\prime} H\right)$-one (7r). White solid; M.F: $\mathrm{C}_{30} \mathrm{H}_{26} \mathrm{O}_{4}$; mp: $126-128{ }^{\circ} \mathrm{C}$; yield: $85 \%$; IR $(\mathrm{KBr}$, $\mathrm{cm}^{-1}$ ): 2958, 1691, 1620, 1290, 1147; ${ }^{1} \mathrm{H} \mathrm{NMR}\left(400 \mathrm{MHz}, \mathrm{CDCl}_{3}\right.$ ) $\delta 8.30(\mathrm{~s}, 1 \mathrm{H}), 8.13-8.11(\mathrm{~d}, J=8.5 \mathrm{~Hz}, 2 \mathrm{H}), 7.74-7.72(\mathrm{~d}, J=$ $8.5 \mathrm{~Hz}, 2 \mathrm{H}), 7.59-7.57(\mathrm{~d}, J=8.0 \mathrm{~Hz}, 2 \mathrm{H}), 7.31-7.29(\mathrm{~d}, J=$ $8.0 \mathrm{~Hz}, 2 \mathrm{H}), 7.04(\mathrm{~s}, 1 \mathrm{H}), 2.91(\mathrm{~s}, 2 \mathrm{H}), 2.62(\mathrm{~s}, 3 \mathrm{H}), 2.42(\mathrm{~s}, 3 \mathrm{H})$, 2.14-2.08 (m, 2H), 1.92-1.88 (m, 2H), $1.77-1.67(\mathrm{~m}, 4 \mathrm{H}) ;{ }^{13} \mathrm{C}$ NMR $\left(100 \mathrm{MHz}, \mathrm{CDCl}_{3}\right) \delta 192.2,184.7,160.7,158.7,149.2,145.4$, $138.1,137.0,136.0,130.2$, 129.6, 128.3, 127.1, 126.7, 124.1, 121.1, 118.9, 100.6, 90.6, 47.1, 37.5, 23.8, 21.1, 10.0; MS (EI mass): $m / z, 450[\mathrm{M}]^{+}$.

4.4.2.19 3'-Methyl-2'-(4-(naphthalen-1-yl)benzoyl)spiro[cyclopentane-1, $7^{\prime}$-furo[3,2-g]chromen]-5'(6'H)-one (7s). White solid; M.F: $\mathrm{C}_{33} \mathrm{H}_{26} \mathrm{O}_{4}$; mp: $170-172{ }^{\circ} \mathrm{C}$; yield: $84 \%$; IR $\left(\mathrm{KBr}, \mathrm{cm}^{-1}\right)$ : 2928, 1680, 1623, 1248, 1152; ${ }^{1} \mathrm{H}$ NMR (400 MHz, $\left.\mathrm{CDCl}_{3}\right) \delta 8.32$ (s, $1 \mathrm{H}), 8.20-8.18$ (d, $J=8.5 \mathrm{~Hz}, 2 \mathrm{H}), 7.95-7.90$ (m, 3H), 7.67-7.65 (d, $J=8.5 \mathrm{~Hz}, 2 \mathrm{H}), 7.58-7.45(\mathrm{~m}, 4 \mathrm{H}), 7.07(\mathrm{~s}, 1 \mathrm{H}), 2.91(\mathrm{~s}, 2 \mathrm{H}), 2.67$ (s, 3H), 2.14-2.09 (m, 2H), 1.92-1.88 (m, 2H), 1.75-1.68 (m, 4H); 
${ }^{13} \mathrm{C}$ NMR $\left(100 \mathrm{MHz}, \mathrm{CDCl}_{3}\right) \delta 192.2,184.8,160.7,158.8,149.1$, 145.4, 139.0, 136.4, 133.7, 131.1, 130.0, 129.6, 128.3, 127.8, 126.9, 126.3, 125.9, 125.6, 125.3, 124.1, 121.2, 118.9, 100.7, 90.6, 47.1, 37.4, 23.8, 10.0; MS (ESI mass): $m / z, 487[\mathrm{M}+\mathrm{H}]^{+}$.

4.4.2.20 2'-(3',5'-Dichloro-[1,1'-biphenyl]-4-carbonyl)-3'-methylspiro[cyclopentane-1, $7^{\prime}$-furo[3,2-g]chromen]- $5^{\prime}\left(6^{\prime} H\right)$-one (7t). White solid; M.F: $\mathrm{C}_{29} \mathrm{H}_{22} \mathrm{Cl}_{2} \mathrm{O}_{4}$; mp: $187-188{ }^{\circ} \mathrm{C}$; yield: $88 \%$; IR $\left(\mathrm{KBr}, \mathrm{cm}^{-1}\right): 2924,1694,1617,1234,1152 ;{ }^{1} \mathrm{H}$ NMR $(400 \mathrm{MHz}$, $\left.\mathrm{CDCl}_{3}\right) \delta 8.31(\mathrm{~s}, 1 \mathrm{H}), 8.16-8.13(\mathrm{~d}, J=8.5 \mathrm{~Hz}, 2 \mathrm{H}), 7.70-7.68(\mathrm{~d}, J$ $=8.5 \mathrm{~Hz}, 2 \mathrm{H}), 7.53(\mathrm{~d}, J=1.7 \mathrm{~Hz}, 2 \mathrm{H}), 7.40(\mathrm{~d}, J=1.7 \mathrm{~Hz}, 1 \mathrm{H})$, $7.04(\mathrm{~s}, 1 \mathrm{H}), 2.91(\mathrm{~s}, 2 \mathrm{H}), 2.64(\mathrm{~s}, 3 \mathrm{H}), 2.14-2.08(\mathrm{~m}, 2 \mathrm{H}), 1.92-$ 189 (m, 2H), 1.76-1.69 (m, 4H); ${ }^{13} \mathrm{C}$ NMR (100 MHz, $\mathrm{CDCl}_{3}$ ) $\delta$ 192.1, 184.4, 160.8, 158.7, 148.9, 142.9, 142.4, 137.3, 135.5, 130.3, 128.2 , 127.9, 126.9, 125.7, 124.0, 121.2 , 119.0, 100.6, 90.6, 47.1, 37.5, 23.8, 10.0; MS (ESI mass): $m / z, 505[\mathrm{M}+\mathrm{H}]^{+}$.

4.4.2.21 2'-(4'-Fluoro-[1.1'-biphenyl]-4-carbonyl)-3'-methylspiro[cyclopentane-1.7' $[3,2-g]$ chromen]- $5^{\prime}\left(6^{\prime} H\right)$-one (7u). White solid; M.F: $\mathrm{C}_{29} \mathrm{H}_{23} \mathrm{FO}_{4}$; mp: $138-140{ }^{\circ} \mathrm{C}$; yield: $85 \%$; IR $(\mathrm{KBr}$, $\left.\mathrm{cm}^{-1}\right):$ 2934, 1675, 1614, 1326, 1236, 1149; ${ }^{1} \mathrm{H}$ NMR $(400 \mathrm{MHz}$, $\left.\mathrm{CDCl}_{3}\right) \delta 8.23(\mathrm{~s}, 1 \mathrm{H}), 8.07-8.05(\mathrm{~d}, J=8.5 \mathrm{~Hz}, 2 \mathrm{H}), 7.63-7.61(\mathrm{~d}, J$ $=8.5 \mathrm{~Hz}, 2 \mathrm{H}), 7.58-7.55(\mathrm{t}, J=8.7 \mathrm{~Hz}, 2 \mathrm{H}), 7.13-7.08(\mathrm{t}, J=$ $8.7 \mathrm{~Hz}, 2 \mathrm{H}), 6.97(\mathrm{~s}, 1 \mathrm{H}), 2.84(\mathrm{~s}, 2 \mathrm{H}), 2.56(\mathrm{~s}, 3 \mathrm{H}), 2.06-2.01(\mathrm{~m}$, $2 \mathrm{H}), 1.86-1.81(\mathrm{~m}, 2 \mathrm{H}), 1.51(\mathrm{~s}, 2 \mathrm{H}), 1.28(\mathrm{~s}, 2 \mathrm{H}) ;{ }^{13} \mathrm{C}$ NMR (100 $\left.\mathrm{MHz}, \mathrm{CDCl}_{3}\right) \delta 192.2,184.6,160.7,158.7,149.1,144.3,136.3$, 130.3, 128.8, 127.8, 126.8, 124.0, 121.2, 118.9, 116.0, 115.7, 100.6, 90.6, 47.1, 37.5, 29.6, 23.8, 10.0; MS (ESI mass): $m / z, 455[\mathrm{M}+\mathrm{H}]^{+}$.

\section{Biological methodologies}

\subsection{Anti-inflammatory}

The anti-inflammatory activity of synthesized compounds was studied by using inhibition of albumin denaturation technique according to Mizushima et al. ${ }^{41}$ and Sakat et al. ${ }^{42}$ followed with minor modifications. The reaction mixture consists of test compounds and $1 \%$ aqueous solution of bovine albumin fraction, at $\mathrm{pH}$ 7.4. The reaction mixture was adjusted using small amounts of $1 \mathrm{~N} \mathrm{HCl}$. The sample extracts were incubated at $37^{\circ} \mathrm{C}$ for $20 \mathrm{~min}$ and then heated to $51^{\circ} \mathrm{C}$ for $20 \mathrm{~min}$, after cooling the samples the turbidity was measured at $660 \mathrm{~nm}$. The percentage inhibition of protein denaturation was calculated as follows:

Percentage inhibition $=($ abs control - abs sample $) \times 100 / a b s$ control with reference to coefficient to correlation coefficient value (r) of 0.946

\subsection{Antioxidant}

5.2.1 DPPH radical scavenging activity. The radical scavenging activity of synthesized compounds was determined by using DPPH (2,2-diphenyl-1-picrylhydrazyl) assay following Chang et al. ${ }^{43}$ method. The decrease in the absorption of the DPPH solution after the addition of test compound or standard antioxidant was measured at $517 \mathrm{~nm}$. Ascorbic acid $(10 \mathrm{mg}$ $\mathrm{mL}^{-1}$ DMSO) was used as reference. Principle 1,1-diphenyl-2picrylhydrazyl is a stable (in powder form) free radical with red color which turns yellow when scavenged. The DPPH assay uses this character to show free radical scavenging activity. The scavenging reaction between (DPPH) and an antioxidant (HA) can be written as,

$$
(\mathrm{DPPH})+(\mathrm{H}-\mathrm{A}) \rightarrow \mathrm{DPPH}-\mathrm{H}+(\mathrm{A})
$$

Antioxidants react with DPPH and reduce it to DPPH-H and as a consequence the absorbance decreases. The degree of discoloration indicates the scavenging potential of the antioxidant compounds or extracts in terms of hydrogen donating ability. The DPPH free radical scavenging assay was performed by following below method. $200 \mu \mathrm{L}$ of $0.1 \mathrm{mM} \mathrm{DPPH}$ prepared in methanol was added to different concentrations of compounds $(0.1$ to $500 \mu \mathrm{M})$. The resulting mixture was incubated at room temperature in the dark for 15 minutes. Absorbance was observed at $517 \mathrm{~nm}$. Ascorbic acid was taken as a positive control. The experiment was carried out in triplicates and percentage inhibition of the DPPH radical scavenging activity was calculated.

$$
\% \text { Inhibition }=\left(\left(A_{0}-A_{1}\right) / A_{0}\right) \times 100
$$

where $A_{0}$ is the absorbance of the control and $A_{1}$ is the absorbance of the sample.

5.2.2 Hydrogen peroxide scavenging assay. The solution of hydrogen peroxide $(100 \mathrm{mM})$ was prepared by the addition of various concentrations of compound $\left(10-200 \mu \mathrm{g} \mathrm{mL} \mathrm{m}^{-1}\right)$ to hydrogen peroxide solution $(2 \mathrm{~mL})$ in phosphate buffer saline of $\mathrm{pH}$ 7.4. Absorbance of hydrogen peroxide at $230 \mathrm{~nm}$ was determined after $10 \mathrm{~min}$ against a blank solution containing phosphate buffer without hydrogen peroxide. For each concentration, a separate blank sample was used for background subtraction. For control sample, absorbance of hydrogen peroxide solution was taken at $230 \mathrm{~nm}$. The percentage inhibition activity was calculated from the formula $\left[\left(A_{0}-A_{1}\right) / A_{0}\right] \times 100$, where $A_{0}$ is the absorbance of the control, and $A_{1}$ is the absorbance of test/standard taken as ascorbic acid (50-300 $\left.\mu \mathrm{g} \mathrm{mL}{ }^{-1}\right)$.

\section{Molecular modeling studies}

To gain more insight into the interactions of spirofurochromanone derivatives $\mathbf{5 a - i}$ and $7 \mathbf{a}-\mathbf{u}$, molecular docking studies were performed. Crystal structure of bovine serum albumin in complex with 3,5-diiodosalicylic acid (PDB id: $4 \mathrm{JK} 4)^{44}$ and COX-2 (PDB id: $\left.3 \mathrm{NTG}\right)^{34}$ were downloaded from protein data bank (www.rcsb.org). Interactions of the molecules with the proteins were analyzed to identify their hypothetical binding mode. All the molecular modeling calculations were performed using Schrödinger Suite 2010 (ref. 35) on Linux platform. The protein was prepared using protein preparation module applying the default parameters, hydrogen atoms were added and unwanted water molecules were removed from the protein structure followed by hydrogen bond optimization and energy minimization. Sitemap ${ }^{36}$ analysis was performed on Bovine Serum Albumin (BSA) as it had many co-crystallized ligands in it. Five top binding cavities were selected and grid 
was generated around these (binding site are represented in the Table 7). In case of COX-2, grid was generated around the active site defined by the co-crystallized ligand. Receptor Van der Waals scaling for the nonpolar atoms was set to $0.9 .{ }^{37}$ Molecules were built using Maestro build panel and prepared by LigPrep OPLS_2005 force. GLIDE 5.6 was used for molecular docking. Low energy conformation of the ligands was selected and docked into the grid using extra precision (XP) docking mode. Further the absorption, distribution, metabolism and excretion (ADME) properties were calculated using Qikprop module in Schrodinger Suite.

\section{Acknowledgements}

This work was supported by UGC (University Grants Commission) as UGC-MRP, Project sanction letter No: F. 43-211/2014 (SR). New Delhi, and is gratefully acknowledged. Our regards to CSIR, for their financial support to M. D. Alaparthi. We thank Head, Department of Chemistry, Osmania University, Hyderabad for providing laboratory facilities. We also thank CFRD and IICT analytical team for providing spectral analytical facilities.

\section{References}

1 P. Ningappa Tatti, S. Anitha, S. Shashidhara, M. Deepak and B. Sanjeevkumar, Int. J. Pharm. Sci., 2012, 3, 2314.

2 N. H. Grant, H. E. Alburnand and C. Kryzanauska, Biochem. Pharmacol., 1970, 715.

3 L. A. D. Williams, A. O'Connar, L. Latore, O. Dennis, S. Ringer, J. A. Whittaker, et al., West Indian Med. J., 2008, 57, 327.

4 L. A. D. Williams, West Indian Med. J., 2009, 58, 191.

5 N. T. S. Phan, D. H. Brown and P. Styring, Tetrahedron Lett., 2004, 4, 7915.

6 Q. N. Chun Liu, F. Bao and J. Qiu, Green Chem., 2011, 13, 1270.

7 S. I. El-Desoky, F. A. Badria, M. A. Abozeid, E. A. Kandeel and A. H. Abdel-Rahman, Med. Chem. Res., 2013, 22, 2105.

8 P. Hezky, I. Krejci, S. Radl, J. Urbankova and P. Vachal, Collect. Czech. Chem. Commun., 2000, 75, 280.

9 D. Dauzonne, J. M. Gillardin, F. Lepage and R. Pointet, Eur. J. Med. Chem., 1995, 30, 53.

10 J. Brady, Y. Hayakawa, M. J. Smyth and S. L. Nutt, J. Immunol., 2004, 172, 2048.

11 J. M. Elliott, H. G. Selnick, D. A. Claremon, J. J. Baldwin, S. A. Buhrow, J. W. Butcher, C. N. Habecker, S. W. King, J. J. Lynch Jr, B. T. Phillips, G. S. Ponticello, E. M. Radzilowski, D. C. Remy, R. B. Stein, J. I. White and M. B. Young, J. Med. Chem., 1992, 35, 3973.

12 J. D. Rizzo, M. T. Flavin, A. Khilevich, A. Kucherenko, A. K. Sheinkman, V. Vilaychack, L. Lin, W. Chen, E. M. Greenwood, T. Pengsuparp, J. M. Pezzuto, T. M. Hughes Shf, M. Cibulski, W. A. Boulanger, R. L. Shone and Z. Q. Xu, J. Med. Chem., 1996, 39, 1303.

13 T. Yamakawa, H. Jona, K. Niiyama, K. Yamada, T. Iino, M. Ohkubo, H. Imamura, J. Shibata, J. Kusunoki and L. Yang, WO 2007011809 A1, 2007.
14 G. Morriello, L. Yang, K. Prendergast, K. Cheng, T. Jacks, W. W. S. Chan, K. D. Schleim, R. G. Smith and A. A. Patchett, Bioorg. Med. Chem. Lett., 1998, 8, 107.

15 S. B. S. Nikolic, M. Brands, U. Niewohner, A. Paessens, E. Graef, K. H. Schlemmer, K. Henninger, R. Endermann, O. Weber and D. Koletzki, US Pat. 20020082274, 2002.

16 H. Abolhasani, S. Dastmalchi, M. Hamzeh-Mivehroud, B. Daraei and A. Zarghi, Med. Chem. Res., 2016, 25, 858.

17 J. Walsh and A. Bell, Curr. Pharm. Des., 2009, 15, 2970.

18 D. A. Viegas-Junior, V. da Silva Bolzani, E. J. Barreiro and C. A. Fraga, Curr. Med. Chem., 2007, 14, 1829.

19 M. Eric, K. N. Guantai, T. J. Egan, J. Gut, P. J. Rosenthal, P. J. Smith and K. Chibale, Bioorg. Med. Chem., 2010, 18, 8243.

20 J. M. Uwe Schön, S. Eichner and A. Kirschning, Tetrahedron Lett., 2008, 49, 3204.

21 D. Ashok, K. Sudershan and M. Khalilullah, Green Chem. Lett. Rev., 2012, 5, 121.

22 D. Ashok and D. Shravani, Tetrahedron Lett., 2008, 49, 7227.

23 D. Ashok, D. Mohan Gandhi, A. Vikaskumar, G. Srinivas, M. Srinivas Reddy, S. SreeKanth and M. Vijjulatha, Med. Chem. Res., 2016, 25, 2882.

24 M. Mujahid, P. Yogeeswari, D. Sriram, U. M. V. Basavanag, E. Díaz-Cervantes, L. Córdoba-Bahena, J. Robles, R. G. Gonnade, M. Karthikeyan, R. Vyas and M. Muthukrishnan, RSC Adv., 2015, 5, 106448.

25 D. Ashok, B. V. Lakshmi and M. Sarasija, Lett. Org. Chem., 2017, 13, 77.

26 R. B. Sanjay and B. W. Suresh, Beilstein J. Org. Chem., 2011, 7, 310.

27 B. Bartolome, V. Nunez, M. Monagas and C. GomezCordoves, Eur. Food Res. Technol., 2004, 218, 173.

28 J. S. Wright, Chem. Br., 2003, 39, 25.

29 K. R. Raghavendra, N. Renuka, V. H. Kameshwar, B. Srinivasan, K. Ajay Kumar and S. Sheena, Bioorg. Med. Chem. Lett., 2016, 26, 3621.

30 D. Costa, A. Gomes, S. Reis, J. L. F. C. Lima and E. Fernandes, Life Sci., 2005, 76, 2841.

31 D. C. Carter and J. X. Ho, Adv. Protein Chem., 1994, 45, 153. 32 G. Sudlow, D. J. Birkett and D. N. Wade, Mol. Pharmacol., 1975, 11, 824.

33 G. Sudlow, D. J. Birkett and D. N. Wade, Mol. Pharmacol., 1976, 12, 1052.

34 J. L. Wang, D. Limburg, M. J. Graneto, J. Springer, J. R. Hamper, S. Liao, J. L. Pawlitz, R. G. Kurumbail, T. Maziasz, J. J. Talley, J. R. Kiefer and J. Carter, Bioorg. Med. Chem. Lett., 2010, 20, 7159.

35 Schrödinger, LLC, 2010, New York, Ligprep, Glide 5.6, Sitemap, Qikprop.

36 T. A. Halgren, J. Chem. Inf. Model., 2009, 49, 377.

37 R. A. Friesner, J. L. Banks and R. B. Murphy, J. Med. Chem., 2004, 47, 1739.

38 G.-F. Shen, T.-T. Liu, Q. Wang, M. Jiang and J.-H. Shi, J. Photochem. Photobiol., B, 2015, 153, 380.

39 N. Rajendiran and J. Thulasidhasan, J. Lumin., 2016, 31, 1438. 
40 C. A. Lipinski, F. Lombardo, B. W. Dominy and P. J. Feeney, Adv. Drug Delivery Rev., 1997, 23, 3.

41 Y. Mizushima and M. Kobayashi, J. Pharm. Pharmacol., 1968, 20, 169.

42 S. Sakat, A. R. Juvekar and M. N. Gambhire, Int. J. Pharm. Pharm. Sci., 2010, 2, 146.
43 S. T. Chang, J. H. Wu, S. Y. Wang, P. L. Kang, N. S. Yang and L. F. Shyur, J. Agric. Food Chem., 2001, 49, 3420.

44 K. Zielinski, A. Bujacz, B. Sekula and G. Bujacz, Int. J. Biol. Macromol., 2013, 60C, 316. 